\title{
Aqueous system-level processes and prokaryote assemblages in the ferruginous and sulfate-rich bottom waters of a post-mining lake
}

\author{
Daniel A. Petrash ${ }^{1,2}$, Ingrid M. Steenbergen ${ }^{1,3}$, Astolfo Valero ${ }^{1,3}$, Travis B. Meador ${ }^{1,3}$, Tomáš Pačes ${ }^{2}$, \\ Christophe Thomazo ${ }^{4,5}$
}

$5 \quad{ }^{1}$ Biology Centre of the Czech Academy of Sciences, České Budějovice, 370 05, Czechia

${ }^{2}$ Czech Geological Survey, Prague, 152 00, Czechia

${ }^{3}$ University of South Bohemia, České Budějovice, 370 05, Czechia

${ }^{4}$ University of Burgundy, Dijon, 21000, France

${ }^{5}$ Institut Universitaire de France, Paris, 75000, France

Correspondence to: Daniel A. Petrash (petrash@ualberta.ca)

\begin{abstract}
In the aqueous oligotrophic ecosystem of a post-mining lake (Lake Medard, Czechia), reductive Fe(II) dissolution outpaces sulfide generation from microbial sulfate reduction (MSR), and ferruginous conditions occur without quantitative sulfate depletion. An isotopically constrained estimate of the rates of sulfate reduction (SRR) suggests that despite a high genetic potential, this respiration pathway may be limited by the rather low amounts of metabolizable organic carbon. This points to substrate competition exerted by iron and nitrogen respiring prokaryotes. Yet, the microbial succession across the nitrogenous and ferruginous zones of the bottom water column also indicates sustained genetic potential for chemolithotrophic sulfur oxidation. Therefore, our isotopic SRR estimates could be rather portraying high rates of anoxic sulfide oxidation to sulfate, probably accompanied by microbially induced disproportionation of S intermediates. Near and at the anoxic sediment-water interface, vigorous sulfur cycling can be fuelled by ferric and manganic particulate matter and redeposited siderite stocks. Sulfur oxidation and disproportionation then appear to prevent substantial stabilization of iron monosulfides as pyrite but can enable the interstitial precipitation of small proportions of equant microcrystalline gypsum. This latter mineral isotopically fingerprints sulfur oxidation proceeding at near equilibrium with the ambient anoxic waters, whilst authigenic pyrite-sulfur displays a 38 to $27 \%$ isotopic offset from ambient sulfate, suggestive of incomplete MSR and likely reflective also of an open sulfur cycling system. Pyrite-sulfur fractionation decreases with increased reducible reactive iron in the sediment. In the absence of ferruginous coastal zones today, the current water column redox stratification in the post-mining Lake Medard has scientific value for (i) testing emerging hypotheses on how a few interlinked biogeochemical cycles operated in nearshore paleoenvironments during redox transitional states; and (ii) to acquire insight on how similar early diagenetic redox proxy signals developed in sediments affected by analogue transitional states in ancient water columns.
\end{abstract}


https://doi.org/10.5194/bg-2021-253

Preprint. Discussion started: 15 November 2021

(c) Author(s) 2021. CC BY 4.0 License.

\section{(c) (i)}

\section{Introduction}

The biogeochemical reactions governing the distinctive redox structure of modern meromictic lakes have been studied, for the most part, in natural settings featuring high concentrations of dissolved iron and with common sulfate deficiency (Swanner et al., 2020). Improved by insights from laboratory experiments (e.g., Konhauser et al., 2007; Rasmussen et al.,

35 2015; Jiang and Tosca, 2019), geochemical and microbiological analyses made in such lacustrine ferruginous systems have provided us with an empirical framework to interpret modern iron biomineralization mechanisms. Natural meromictic lakes are also relevant to decipher specific chemical and isotopic signatures of ferruginous type sediments that are meaningful for paleoenvironmental interpretations. For example, these settings have significantly informed our Precambrian ocean redox stratification models (Crowe et al., 2008; Walter et al., 2014; Koeksoy et al., 2016; Lambrecht et al., 2018; Swanner et al., 40 2020).

Ferruginous bottom water columns that also contain elevated dissolved sulfate concentrations are not uncommon in shallow pit lakes (e.g., Denimal et al., 2005; Trettin et al., 2007), and have also been reported from the post-mining Lake Medard in NW Czechia (Petrash et al., 2018; Fig. 1a). This newly formed, lacustrine system with a $60 \mathrm{~m}$ depth features oligotrophic and meromictic conditions, and given its recent water filling history it can be considered as a large-scale incubation

45 experiment reflecting an imbalanced transitional state between ferruginous and euxinic aquatic redox states (Scholz, 2018; van de Velde et al., 2021). These states are defined by the presence of water column divalent iron $\left(\mathrm{Fe}^{2+}>\mathrm{H}_{2} \mathrm{~S}\right.$ and $\mathrm{Fe}^{2+}>$ $\mathrm{NO}_{3}{ }^{-} / \mathrm{NO}_{2}{ }^{-}$) or dissolved sulfide $\left(\mathrm{H}_{2} \mathrm{~S} / \mathrm{HS}^{-}\right)$, respectively.

Here we combined spectroscopic hydrochemical analyses of the sulfate-rich, dysoxic (i.e., 2.0 to $0.2 \mathrm{mg} \cdot \mathrm{L}^{-1} \mathrm{O}_{2}$ ), nitrogenous and ferruginous (suboxic) and ultimately anoxic $\left(<0.03 \mathrm{mg} \cdot \mathrm{L}^{-1} \mathrm{O}_{2}\right)$ bottom water column of Lake Medard. We interpret

50 system-level processes that can be linked to the presence of specific planktonic prokaryote functionalities within its redox stratified water column. Isotope ratios of carbon and oxygen in dissolved inorganic carbon, sulfur and oxygen in dissolved sulfate, and concentration profiles of bioactive ions and volatile fatty acids (VFAs) were measured together with a 16S rRNA amplicon gene sequence profile. To complement our interpretations, in the upper anoxic sediments we also conducted mineralogical analyses and a mineral-calibrated wet chemical speciation study of the reactive Fe and Mn pools. Using these

55 data, we developed a mechanistic model that assesses the potential regulatory roles of prokaryotes over the geochemical gradients detected in the water column, and their influence over iron $(\mathrm{Fe})$ mineral transformations and biogeochemical cycling of sulfur $(\mathrm{S})$, carbon $(\mathrm{C})$, nitrogen $(\mathrm{N})$ and manganese $(\mathrm{Mn})$ across the redoxcline, and near the anoxic sedimentwater interface $(\mathrm{SWI})$. The consumption and replenishment of these elements are presented as a set of biogeochemical reactions that differentiate the bottom waters in distinctive niches where a phylogenetically and metabolically diverse

60 microbial community induce an active elemental internal cycling involving reactive minerals in the sediments.

Our observations in this unique artificial lacustrine system are thought relevant since analogue aqueous-level system processes would have also punctually operated in ancient ferruginous coastal settings. Lake Medard could therefore offer valuable information to further understand the roles played by comparable microbial aqueous ecosystems in mineral 
https://doi.org/10.5194/bg-2021-253

Preprint. Discussion started: 15 November 2021

(c) Author(s) 2021. CC BY 4.0 License.

authigenesis in the past. In addition, our research furthers understanding of the cryptic S cycle under ferruginous conditions unaccompanied by a quantitative sulfate exhaustion, and for refining our proxy-based palaeoceanographic reconstructions of nearshore redox stratified water columns.

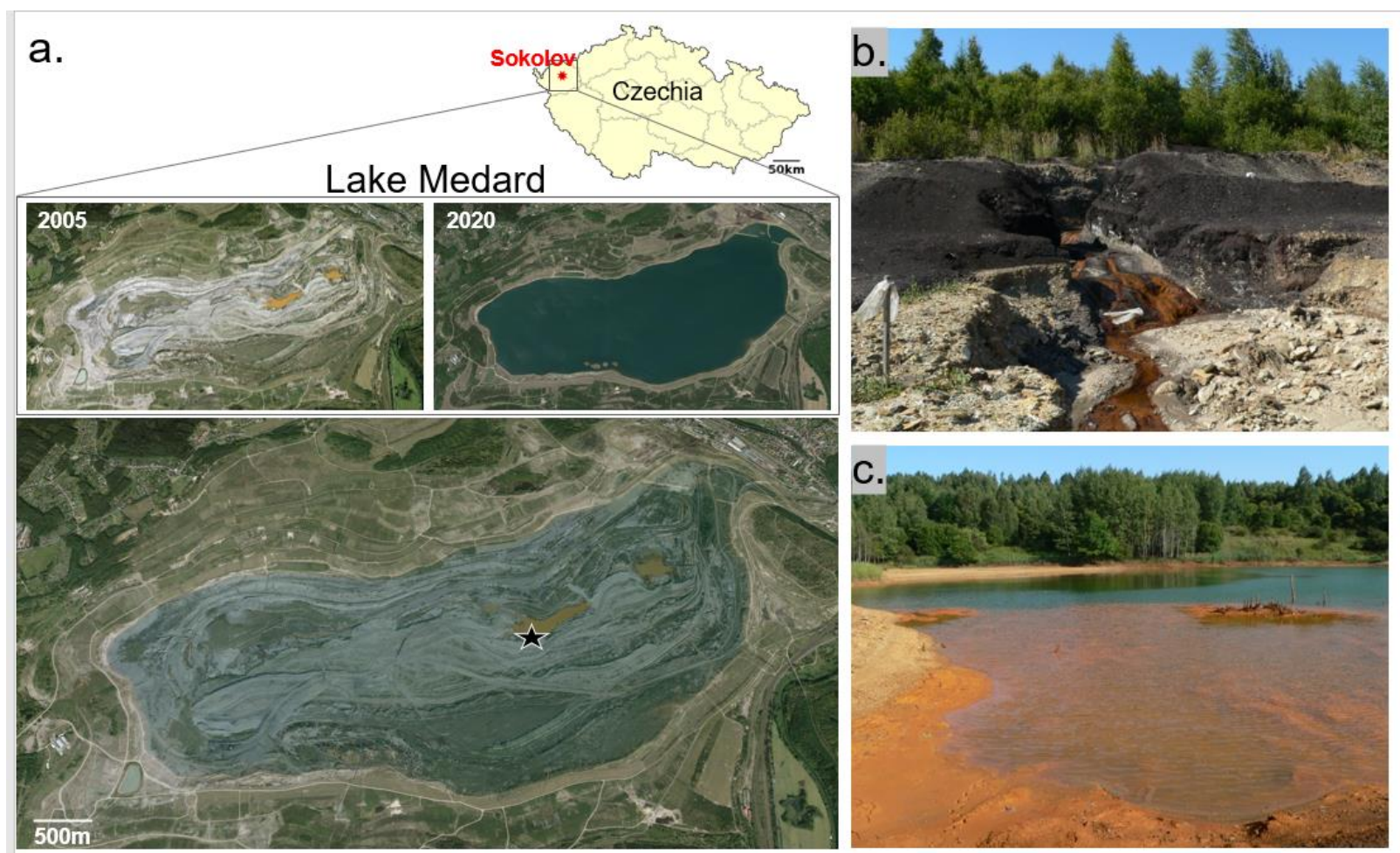

Figure 1. The area now occupied by the post-mining Lake Medard was previously an open cast coal mine near Sokolov, NW Czechia. Upon mine abandonment, the deepest parts of the open cast mine became shallow acidic pit lakes and are now the postmining lake depocenters. These feature ferruginous and sulfate-rich aqueous conditions. The star marks the central sampling location in a recent lake imagery superimposed on the 2005 mine-pit imagery. The mine-pit had important fluxes of solutes linked to pyrite oxidation in exploited coal seams and their associated pyrite-bearing lithologies. These fluxes may still affect the hydrochemistry of the present-day lacustrine system, i.e., solutes are now sourced from now submerged lithologies (b-c). Imagery dates 5/19/2020 (CCNES/Airbus) and 1/1/2004 (CGEODIS Brno). Historical photographic record by courtesy of The Czech Geological Survey.

\section{Study site}

Reclamation (flooding) of land occupied by the decommissioned Medard open-cast lignite mine in the Sokolov mining district of Karlovy Vary, northwest Czechia, led to the ca. 4.9 km² ( 60 m max. depth) post-mining Lake Medard (Fig. 1a; $\left.50^{\circ} 10^{\prime} 41^{\prime \prime} \mathrm{N}, 12^{\circ} 35^{\prime} 46^{\prime \prime} \mathrm{E}\right)$. The lake was filled with waters diverted for reclamation purposes from the nearby Eger River.

80 During closure and abandonment of the former lignite mine, dissolved iron, and sulfate - derived from pyrite oxidation, leached towards shallow pit lakes as mining operation ceased and surficial and groundwaters filled the open-cast mine (Fig. 1b-c). In the mining-impacted brines metastable Fe(III)-oxyhydroxides and -oxyhydroxysulfates precipitated (Murad and 
https://doi.org/10.5194/bg-2021-253

Preprint. Discussion started: 15 November 2021

(c) Author(s) 2021. CC BY 4.0 License.

\section{(c) (i)}

Rojík, 2005). Runoff also affected the hydrochemistry of these shallow water bodies (Fig. 1b-c) by carrying solutes sourced from a Miocene sedimentary unit (Cypris Formation) that overlies the mined coal seam. The detrital material consists of fine

85 grained minerals (silt to clay in size); derived from a tuffaceous and carbonate-rich lacustrine claystone described in detail by Kř́bek et al. (2017).

Water-rock interactions in the underlying granitic basement also influenced the hydrochemistry of a Miocene playa lake (Rapantová et al., 2012) that extend across the area now occupied by Lake Medard. In the fractures of the crystalline basement rocks, percolation of waters from that paleolake produced epithermal mineral salt deposits in the form of localized

90 thernadite $\left(\mathrm{Na}_{2} \mathrm{SO}_{4}\right)$ efflorescences (Pačes and Šmejkal, 2004). Percolation and subsurface flow of modern meteoric water caused dissolution of the subsurface salts. Thernadite dissolution could have introduced significant loads of isotopically heavy sulfate into the present-day hydrogeological system (Pačes and Šmejkal, op. cit.). Additional details on the geological framework of the area, and its ongoing influence over the hydrochemistry of the more recently formed, post-mining lacustrine system are provided in Appendix A.

95 At present, Lake Medard is an oligotrophic water body exhibiting density, temperature and redox stratification. Its bottom water column is sulfate-rich and ferruginous. Both, abiotic and microbially mediated precipitation of poorly crystalline iron minerals-i.e., amorphous ferric hydroxide $\left(\mathrm{Fe}(\mathrm{OH})_{3}\right)$ and metastable nanocrystalline ferrihydrite $\left(\mathrm{Fe}_{2} \mathrm{O}_{3} \cdot\left(\mathrm{H}_{2} \mathrm{O}\right)_{\mathrm{n}}\right)-$ occurs near the redoxcline from where these phases are exported to the SWI (Petrash et al., 2018). Mineral equilibrium reactions at the SWI proceed mostly within the suboxic range of redox potential (Eh) and at a circumneutral to moderately alkaline $\mathrm{pH}$. Stability diagrams showcasing the predicted stability of $\mathrm{S}$ and Fe species in the bottom waters of Lake Medard are shown in Fig. B1 (Appendix B).

\section{Methods}

A water quality monitoring and profiling probe was used to measure density, temperature, and redox potential in the stratified bottom water column of Lake Medard prior to sampling. On aliquots of our water samples, we performed (i) MiSeq Illumina 16S rRNA gene amplicon sequencing, (ii) mass spectroscopic determinations of ion and cation concentrations, (iii) dissolved inorganic carbon and methane concentrations, (iv) $\delta^{13} \mathrm{C}$ analysis of total dissolved inorganic carbon and methane, (v) $\delta^{34} \mathrm{~S}$ and $\delta^{18} \mathrm{O}$ of dissolved sulfate, and (vi) VFAs concentration analyses. We also sampled the upper anoxic sediment column to a depth of $\sim 8 \mathrm{~cm}$. The mineralogy of these sediments was qualitatively and semi-quantitatively assessed via $\mathrm{X}$-ray diffraction (XRD). The $\delta^{34} \mathrm{~S}$ and $\delta^{18} \mathrm{O}$ isotope ratios of gypsum $\left(\mathrm{CaSO}_{4} \cdot 2 \mathrm{H}_{2} \mathrm{O}\right), \delta^{13} \mathrm{C}$ of siderite $\left(\mathrm{FeCO}_{3}\right)$, and $\delta^{34} \mathrm{~S}$ of pyrite $\left(\mathrm{FeS}_{2}\right)$ from these sediments were also measured. Scanning electron microscopy aided by electron dispersive spectrometry (SEM-EDS) was used for textural analyses focused on the S- and/or Fe-bearing phases. In addition, a sequential extraction scheme (after Poulton et al., 2004; Goldberg et al., 2012) was conducted to characterize the sedimentary partitioning of reactive $\mathrm{Fe}$ and $\mathrm{Mn}$ fractions. Details on the methods and protocols applied for sample collection and preparation, instrumentation, eDNA extraction and16S rRNA gene-based clone libraries preparation are provided in Supplement 1 . The 
https://doi.org/10.5194/bg-2021-253

Preprint. Discussion started: 15 November 2021

(c) Author(s) 2021. CC BY 4.0 License.

(c) (i)

115 metagenomic data for this study (total 1,799,339 read base pairs, mean lengths $\geq 402 \mathrm{bp}$ ) were deposited in the European Nucleotide Archive (ENA) at EMBL-EBI under accession number PRJEB47217 (Accessible from 2022).

\section{Results and discussion}

\subsection{Bottom water column stratification and dissolved oxygen $\left(\mathrm{O}_{2}\right)$ levels}

Figure 2a shows the relevant physicochemical parameters measured in the dysoxic to anoxic bottom waters at the time of

120 sampling (November 2019). Profiling of these parameters is consistent with several previous and subsequent probe monitoring measurements in the meromictic post-mining lake. Conductivity exhibits a steep gradient at ca. $48 \mathrm{~m}$ depth that flattens with increasing depth. Temperature increases gradually towards the bottom. The zone in the water column where these gradients concur is referred to as the hypolimnion. Increased conductivities within the hypolimnion of post-mining lakes, such as examined here, could result from the legacy of the former mine drainage and/or from groundwater inflow

125 (e.g., Denimal et al., 2005; Schultze et al., 2010). Salinity was estimated by using the measured conductivity values (after Hambright et al., 1994). It increases three-fold from the hypolimnion downwards (Fig. 2a). This could result from recharge of groundwater carrying high loads of dissolved salts or results from the lack of mixing of the legacy mine-impacted pit lake waters with those comprising the mixolimnion. The temperature gradient results from limited seasonal vertical heat exchange between the bottom density stratified water column and the mixolimnion (Boehrer and Schultze, 2008).

130 Molecular oxygen $\left(\mathrm{O}_{2}\right)$ from the mixolimnion cannot be replenished below the density and thermally stratified bottom waters, where deoxygenation very likely proceeds through biotic and abiotic reactions involving Fe-oxidation (e.g., Boehrer et al., 2009). Dissolved $\mathrm{O}_{2}$ levels thus drop rapidly from about 8.1 to $\sim 0.2 \mathrm{mg} \cdot \mathrm{L}^{-1}$ within the 48 to $49 \mathrm{~m}$ depth-interval of the water column, and the deepest part of the lake is anoxic (Fig. 2a). At this level, the Eh shifts from $>100 \mathrm{mV}$ at the lower mixolimnion to negative values down to $\leq-230 \mathrm{mV}$ near the SWI. The suboxic to anoxic zone of the water column is

135 referred to as the monimolimnion, with the sharp redox boundary zone being referred to as the redoxcline (Fig. 2a). The hydrochemically different monimolimnion persists in the deepest depressions of the lakebed throughout the year; although with slight variations in the monitored Eh range that could be accompanied by minor $( \pm 1 \mathrm{~m})$ shifts in the vertical position of the redoxcline. In this study, we focus on the central part of the lakebed as it exhibits the broadest Eh range in its bottom water column (Fig. 2a). Details on the eastern and western sampling locations are available in a descriptive study by Petrash

140 et al. (2018). Short-lived changes in redox potential of the bottom water column were recently considered by Umbría-Salinas et al. (2021). These changes have effects on the partitioning of several redox sensitive metals that are bound to reactive iron phases in the upper sediments. 
https://doi.org/10.5194/bg-2021-253

Preprint. Discussion started: 15 November 2021

(c) Author(s) 2021. CC BY 4.0 License.

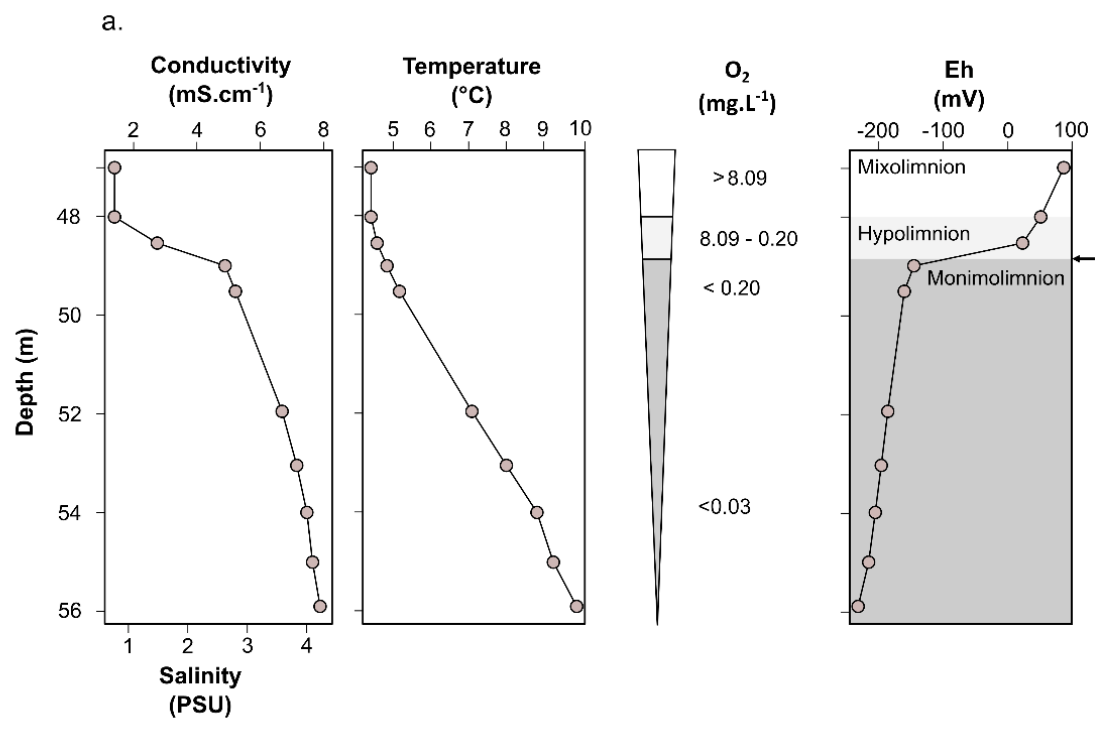

b.

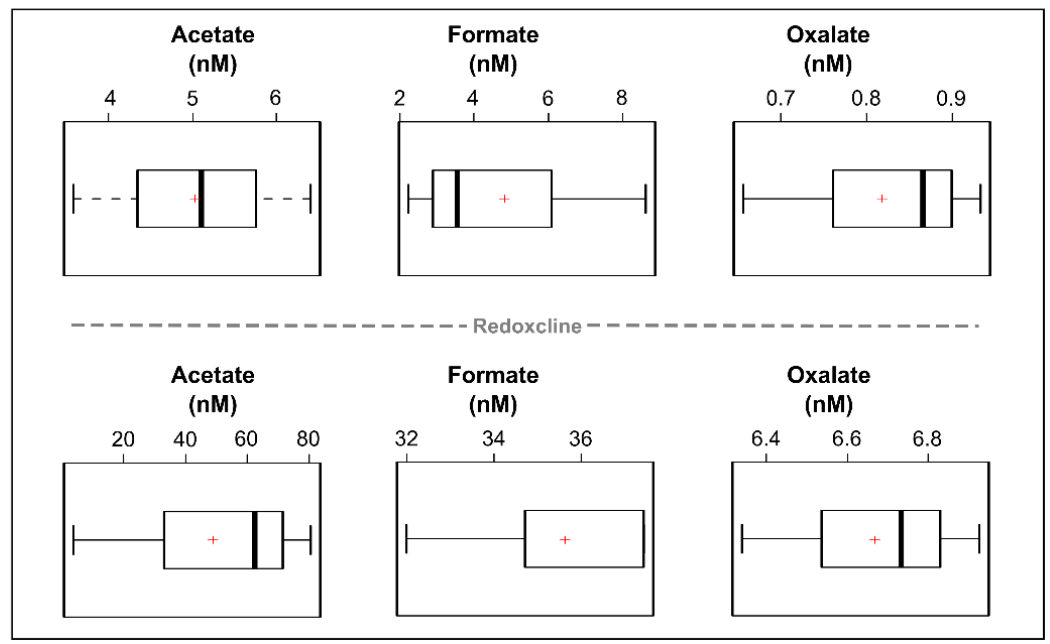

Figure 2. Physicochemical parameters in the bottom dysoxic to anoxic waters of Lake Medard in its central sampling location (a) and concentrations range of discrete VFAs (acetate, formate and oxalate) quantified in the dysoxic $(n=4)$ and anoxic $(n=3)$ waters of Lake Medard (b). The arrow in "a" shows the position of the redoxcline at the time of sampling. For VFAs detection limits were better than $60 \mathrm{ppb}$ for lactate and oxalate, and $200 \mathrm{ppb}$ for butyrate, formate, and acetate.

\subsection{Dissolved carbon concentrations and $\delta^{13} \mathrm{C}$ isotope values}

\subsubsection{Dissolved Organic Carbon (DOC)}

150 The DOC concentrations in the bottom waters sampled were $1.05 \pm 0.5 \mathrm{mM}$. VFAs were at nanomolar concentrations that are reflective of the general scarcity of labile organic substrates in the Lake Medard oligotrophic system. A six- to ten-fold increase in concentrations of acetate, oxalate, and formate occurred towards the increasingly saline and $\mathrm{O}_{2}$-depleted bottom waters. Concentrations of lactate, propionate, and butyrate can be detected at similar nanomolar magnitudes in the 
https://doi.org/10.5194/bg-2021-253

Preprint. Discussion started: 15 November 2021

(c) Author(s) 2021. CC BY 4.0 License.

\section{(c) (1)}

mixolimnion (not shown), but in the bottom waters these VFAs are exhausted and were below our limits of quantification $(<$ LQ) (Fig. 2b).

\subsubsection{Total dissolved inorganic carbon}

The concentrations of total dissolved inorganic carbon (i.e., $\Sigma \mathrm{CO}_{2}=\mathrm{H}_{2} \mathrm{CO}_{3}+\mathrm{HCO}_{3}{ }^{-}+\mathrm{CO}_{3}{ }^{2-}$ ) ranged from 1.9 to $9.8 \mathrm{mM}$ and increased downwards (Fig 4a). The concentrations of this parameter $\left(\left[\Sigma \mathrm{CO}_{2}\right]\right)$ were positively correlated with alkalinity, which ranged from 1.8 to $2.9 \mathrm{meq} \cdot \mathrm{L}^{-1}$ (measured as $\mathrm{HCO}_{3}{ }^{-}$). The $\mathrm{pH}$ in the hypolimnion was $\sim 8.2$ and decreased moderately downwards, reaching $7.4 \pm 0.2$ units near the anoxic SWI. Simultaneous reactions involving dissolution, anoxic reoxidation and (re)precipitation of reactive minerals could be responsible of this moderate decrease in $\mathrm{pH}$ (see Soetaert et al., 2007). These reactions are further considered in subsequent sections of this work.

Total dissolved inorganic carbon exhibited lower $\delta^{13} \mathrm{C}$ values at the anoxic monimolimnion (Table 1, Fig. 3a), and [ $\left.\Sigma \mathrm{CO}_{2}\right]$ were inversely correlated with the $\delta^{13} \mathrm{C}$ values. The concentrations of dissolved sulfate and $\left[\Sigma \mathrm{CO}_{2}\right]$ were inversely correlated too (Fig. 3b-c). From these observations, a contribution of organically derived $\mathrm{CO}_{2}$ is evident, but it could be also argued that in the bottom water column, sulfate reduction has a moderate impact on alkalinity. Although speculative, it is possible that microbial sulfate reduction (MSR) is responsible for lactate depletion in the bottom waters. It could also be a factor contributing to the slight decrease in $\mathrm{pH}$ in the monimolimnion (see Gallagher et al., 2014).

The $\mathrm{CO}_{2}$ source flux at the lake floor can be constrained given that the $\delta^{13} \mathrm{C}$ values in sedimentary carbonates and organic matter are known. A two-component mixing model thus permits estimation of the relative contribution of these carbon sources to the bottom water $\Sigma \mathrm{CO}_{2}$ reservoir. We plotted the $\delta^{13} \mathrm{C}$ signatures of water vs. the inverse of the $\Sigma \mathrm{CO}_{2}$ concentrations, corrected by a mixing factor $\left(\delta^{13} \mathrm{C}=\mathrm{f} \cdot \Sigma \mathrm{CO}_{2}{ }^{-1}+\mathrm{b}\right.$; after Keeling, 1961; Fig. 3d). The intercept " $\mathrm{b}$ " of the linear regression can then be assumed as the isotopic carbon signature of the combined $\mathrm{CO}_{2}$ flux. This approach works, in our case, under the postulate that the $\Sigma \mathrm{CO}_{2}$ flux at the lake floor displays an isotope signature resulting from the admixture of $\mathrm{CO}_{2}$ evolved from both remineralization of the sedimentary organic matter $\left(\delta^{13} \mathrm{C}=-27.9 \pm 0.1 \%\right.$, $\left.\mathrm{n}=6\right)$, and (bi)carbonate ions derived from the dissolution of carbonate phases near the SWI and below. A minor contribution of $\Sigma \mathrm{CO}_{2}$ evolved from the oxidation of methane diffusing throughout the anoxic sediments to the bottom water column (mean $\delta^{13} \mathrm{C}_{\mathrm{CH} 4} \approx-67 \%$; Table 1) might also be possible and was considered. To account for the reactive $\mathrm{C}$ of the sedimentary mineral phases, we used the carbonate $\delta^{13} \mathrm{C}$ mean values in the anoxic sediments $(+6.4 \pm 0.3 \%$ ), which is within the range reported for carbonates in lignite-associated lithologies $\left(\delta^{13} \mathrm{C}\right.$ range: +1.7 to $+13.4 \%$; median $=+9.8 \%$; Šmejkal, 1978,1984$)$. Our sediment's $\delta^{13} \mathrm{C}$ mean value thus fingerprints mostly siderite, which is the only carbonate phase detected via XRD. Yet, other relatively more soluble carbonate phases, such as dolomite and calcite, might be present in small proportions at the lake floor because they occur with siderite in the Miocene Cypris Fm. These would account for only $\leq 0.2$ wt. \% (i.e., the LQ of our semi-quantitative XRD analyses). 
https://doi.org/10.5194/bg-2021-253

Preprint. Discussion started: 15 November 2021

(c) Author(s) 2021. CC BY 4.0 License.

Table 1. Measured concentrations and isotopic ratios in the $\mathbf{O 2}$ depleted bottom water column of the central sampling location (from 47 to $55 \mathrm{~m}$ depth below the surface), Lake Medard.

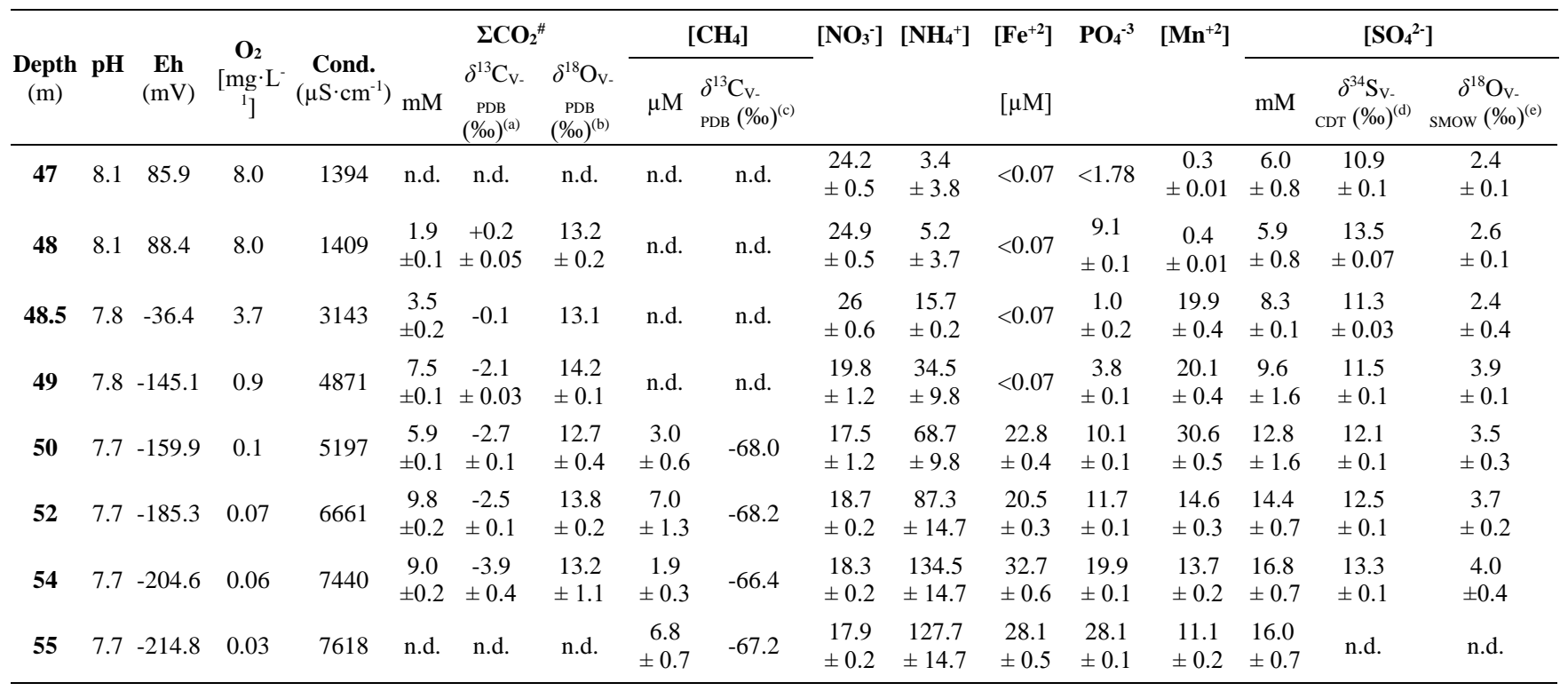

${ }^{\#} \Sigma \mathrm{CO}_{2}=\mathrm{H}_{2} \mathrm{CO}_{3}+\mathrm{HCO}_{3}{ }^{-}+\mathrm{CO}_{3}{ }^{2-}$

Precision of the isotopic values reported - based on repeated measurements of analytical standards (better than;

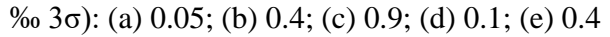

The estimated isotopic $\mathrm{C}$ signature of the $\mathrm{CO}_{2}$ flux at the anoxic sediments is between -3.0 and $-4.2 \%$ (Fig. 3d). This

190 predicted $\delta^{13} \mathrm{C}$ range of values for $\mathrm{CO}_{2}$ diffused into the overlying monimolimnion is within the range observed in emanations regionally releasing magmatically derived $\mathrm{CO}_{2}$ (Weinlich et al., 1999; Dupalová et al., 2012). In other words, the variable contribution of $\mathrm{CO}_{2}$ derived from $\mathrm{OM}$ degradation, carbonate mineral dissolution and any plausible methanotrophic activity produces an isotopic signature in the $\Sigma \mathrm{CO}_{2}$ of the lake bottom water that matches that of the magmatic-derived $\mathrm{CO}_{2}$ emissions.

195 The mixing factor in the simple linear mixing model accounts for the proportional contributions of the sources to the $\Sigma \mathrm{CO}_{2}$ admixture entering the bottom waters (e.g., Phillips and Gregg, 2001). Accordingly, dissolution of sedimentary carbonates accounts for $70 \pm 5 \%$ of the dissolved inorganic carbon, with the remaining fraction being the product of organic matter heterotrophy. The contribution of isotopically light $\mathrm{CO}_{2}$ derived from the oxidation of diffused methane is negligible. Any contribution of $\mathrm{CO}_{2}$ from the magmatic source cannot be estimated because of the similar isotopic signatures. The implication for environmental/early diagenetic interpretations of this approach is that if siderite is formed in the lake sediments, it appears to display a significant $\delta^{13} \mathrm{C}$ offset from the signature of the $\Sigma \mathrm{CO}_{2}$ reservoir of the lake's floor. We will revisit the siderite origin under Sect. 4.6.3. 

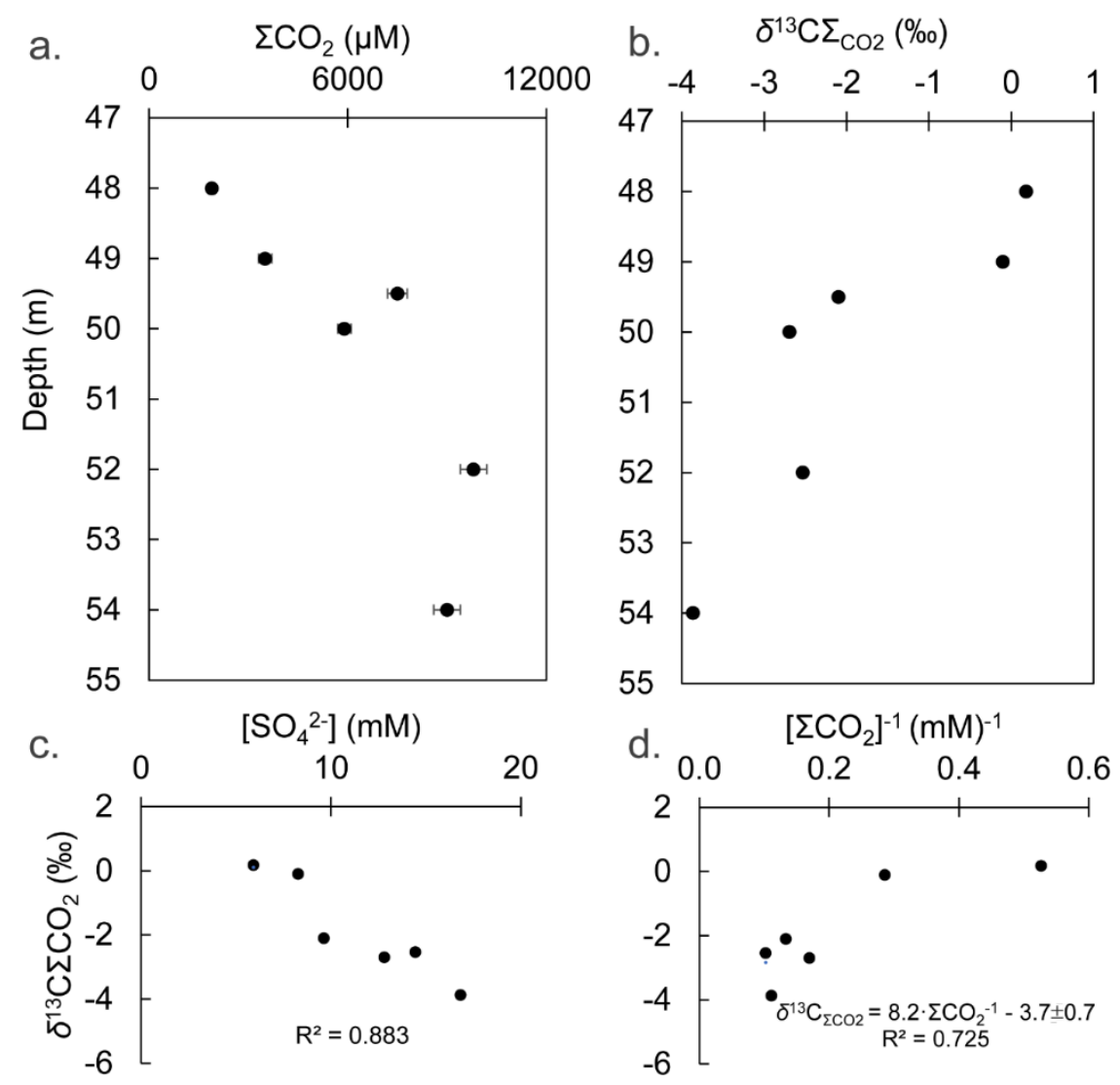

Figure 3. Depth-dependent variation in total dissolved inorganic carbon $\left(\Sigma \mathrm{CO}_{2}\right)$ (a) and its $\delta^{13} \mathrm{C}(\%$, $\mathrm{V}$-PDB) (b) in the oxygen

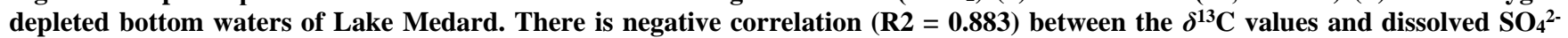
concentrations (c). A Keeling-style plot $\left(\Sigma \mathrm{CO}_{2}\right.$ vs. $\left.\delta^{13} \mathrm{C}_{\Sigma \mathrm{CO} 2}\right)$ was used to deduce the isotopic $\mathrm{C}$ signature of the combined $\mathrm{CO} 2$ flux at the sediment water interface, i.e., the intercept (d).

4.3 Nitrogen, iron and sulfur species in water column with functional annotations on the planktonic prokaryote community with functional annotations on the planktonic prokaryote community

\subsubsection{Nitrogen species transformations and nitrogen-utilizing prokaryotes}

Dissolved nitrate $\left(\mathrm{NO}_{3}^{-}\right)$concentrations across the dysoxic hypolimnion are approximately $25 \mu \mathrm{M}$ and decrease about $28 \%$ towards the anoxic monimolimnion. This decrease in accompanied by a significant increase in ammonium from $16 \mu \mathrm{M}$ to up to $142 \mu \mathrm{M}$ (Table 1; Fig. 4a). Similar behaviour of reactive N species were described in other ferruginous water columns (e.g., Michiels et al., 2017; Lambrecht et al., 2018). 
a.

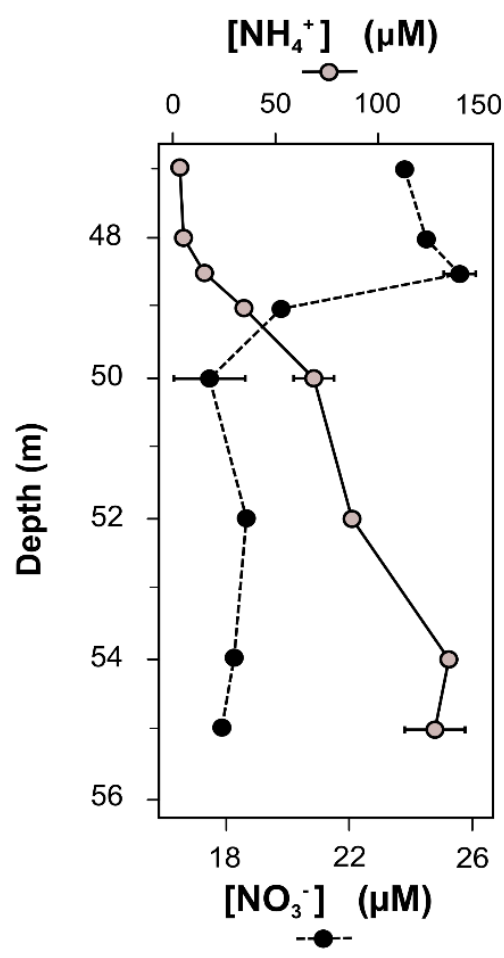

b.
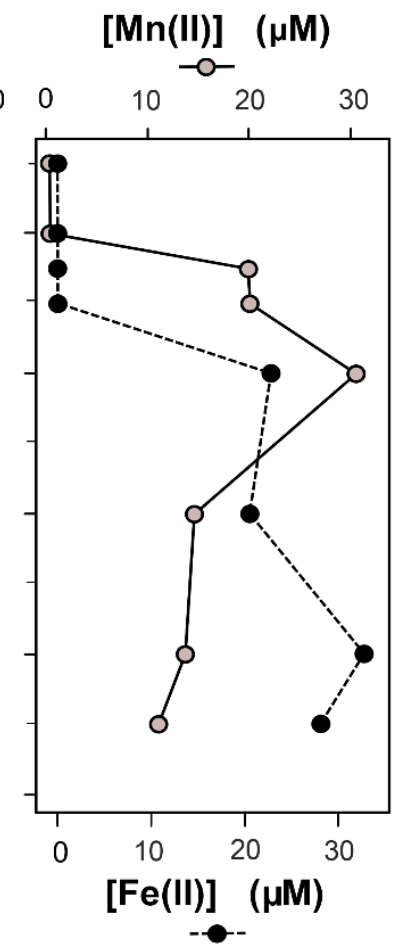

C.
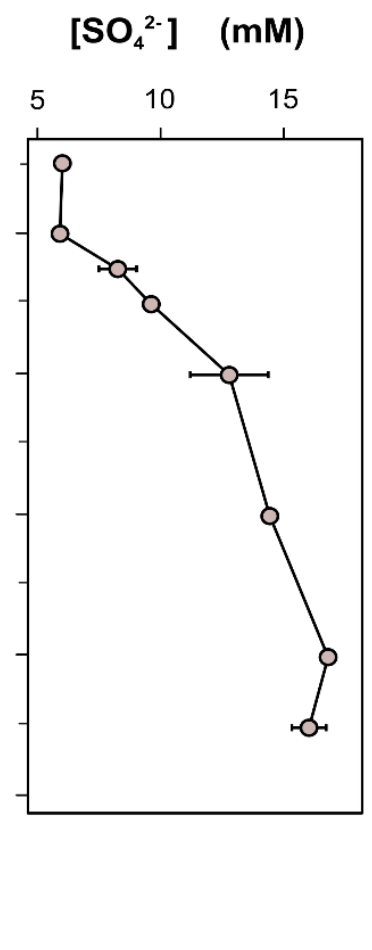

Figure 4. Measured dissolved concentrations of nitrate and ammonia (a), manganous manganese and ferrous iron (b), and (c) sulfate.

The relative abundance of $16 \mathrm{~S}$ rRNA gene sequences that can be ascribed to N-utilizing planktonic prokaryotes indicates that Nitrosomonas-like species (95 to $98 \%$ gen similarity) are in the dysoxic hypolimnion at a low normalized abundance which increases significantly at the redoxcline. Here Nitrosomonas-like species may conduct the first and rate-limiting step in nitrification, i.e., $\mathrm{NH}_{3}$ oxidation (Lehtovirta-Morley, 2018). The second nitrification step, nitrite oxidation to $\mathrm{NO}_{3}$, could be exerted predominantly by species exhibiting similarity ( $98 \%$ gene sequence) to $\mathrm{Ca}$. Nitrotoga. $\mathrm{Ca}$. Nitrotoga was sequenced in all our bottom water column samples but exhibited a higher normalized abundance (up to $9 \%$ ) at the redoxcline (Fig. 5a).

225 Among the relatively abundant, $\mathrm{NH}_{3}$-oxidizing microbes sequenced is an archaeon related to Nitrosarchaeum koreense (97$98 \%$ gen similarity). This archaeon appears to thrive better in the ferruginous waters below the redoxcline (Fig. 5a, also Supplement 2). Its distribution across the redox gradient is at odds with the fact that $N$. koreense has been previously suggested to be an aerobe (Jung et al., 2018). Our observation could make the case for niche differentiation linked to high loads of dissolved metal concentrations conferring a competitive advantage to the $N$. koreense-like microorganism (e.g., 
https://doi.org/10.5194/bg-2021-253

Preprint. Discussion started: 15 November 2021

(c) Author(s) 2021. CC BY 4.0 License.

(c) (i)

230 Gwak et al., 2019). Alternatively, the archaeon sequenced predominantly in the suboxic waters possesses tolerance to anoxia (see Mußmann et al., 2011).

The abundance peak of an Azospira-like microorganism (95\% similarity) coincides with the peak of relative abundance of members of the Gallionellacea family at 49 to $50 \mathrm{~m}$ depth (Fig. 5a, Supplement 2). Like Gallionella, Azospira also possess dissimilatory $\mathrm{N}$ and Fe-based metabolisms capable of yielding dinitrogen $\left(\mathrm{N}_{2}\right)$. $\mathrm{N}_{2}$ production can thus be thought to account

235 for the apparent nitrogen loss observed when the dissolved reactive $\mathrm{NH}_{4}{ }^{+}$and $\mathrm{NO}_{3}{ }^{-}$levels are compared across their counter gradients (Table 1; Fig. 5a).

Comparison of the gradients of abundances of the $\mathrm{N}$ - utilizing prokaryotes with the gradients of other bioactive species is presented in Fig. 4. This suggests that while metabolizing nitrogen the prokaryote community also impacts the cycles of Fe and S (e.g., Jewell et al., 2016, 2017; Starke et al., 2017). These cycles in the aqueous system under consideration are 240 interlinked throughout microbial mediation in the following Rcs. (1-3):

$$
\begin{aligned}
& 10 \mathrm{Fe}^{2+}+2 \mathrm{NO}_{3}{ }^{-}+24 \mathrm{H}_{2} \mathrm{O} \rightarrow 10 \mathrm{Fe}(\mathrm{OH})_{3}+\mathrm{N}_{2}+18 \mathrm{H}^{+} \\
& \mathrm{NO}_{3}{ }^{-}+8 \mathrm{Fe}^{2+}+21 \mathrm{H}_{2} \mathrm{O} \rightarrow \mathrm{NH}_{4}{ }^{+}+8 \mathrm{Fe}(\mathrm{OH})_{3}+14 \mathrm{H}^{+} \\
& 5 \mathrm{HS}^{-}+8 \mathrm{NO}_{3}{ }^{-} \rightarrow 5 \mathrm{SO}_{4}{ }^{2-}+4 \mathrm{~N}_{2}+3 \mathrm{OH}^{-}+\mathrm{H}_{2} \mathrm{O}
\end{aligned}
$$

Reaction 1 proceeds mixotrophically, usually requiring a favourable organic co-substrate, whereas reactions 2 and 3 likely proceed under the influence of chemolithotrophic Fe(II) and/or S oxidizing nitrate reducers. Due to energetic considerations, these microorganisms are known for having metabolic advantages under ferruginous conditions over solely denitrifying organisms (see Robertson and Thamdrup, 2017). Reaction 3 is known to proceed at rather low sulfide levels (Brunet and Garcia-Gil, 1996; Barnard and Russo, 2009), such as those characterizing the monimolimnion of our study site $(\leq 0.3 \mu \mathrm{M})$. In the following section, to further investigate details on the microbial ecology of the bottom ferruginous waters of Lake 250 Medard, we consider the concentration profiles of dissolved Fe and Mn along the redoxcline. Concentrations of these dissolved metals are operationally defined as the combined ionic and colloidal fractions that passed the $0.22 \mu \mathrm{m}$ cut-off of membrane filters. By co-evaluating the dissolved $\mathrm{Fe}$ and $\mathrm{Mn}$ concentration trends, we pursue further insight on the mechanism procuring and/or consuming these metals in the stratified water column (Davidson, 1993). A 16S rRNA gene abundance profile of known iron-utilizing prokaryotes also permitted inferences on what members of the microbial 255 community could be exerting a direct dissimilatory (catabolic), or indirect (via electron transfer) control over the concentration trends of these metals across the redox gradient. 


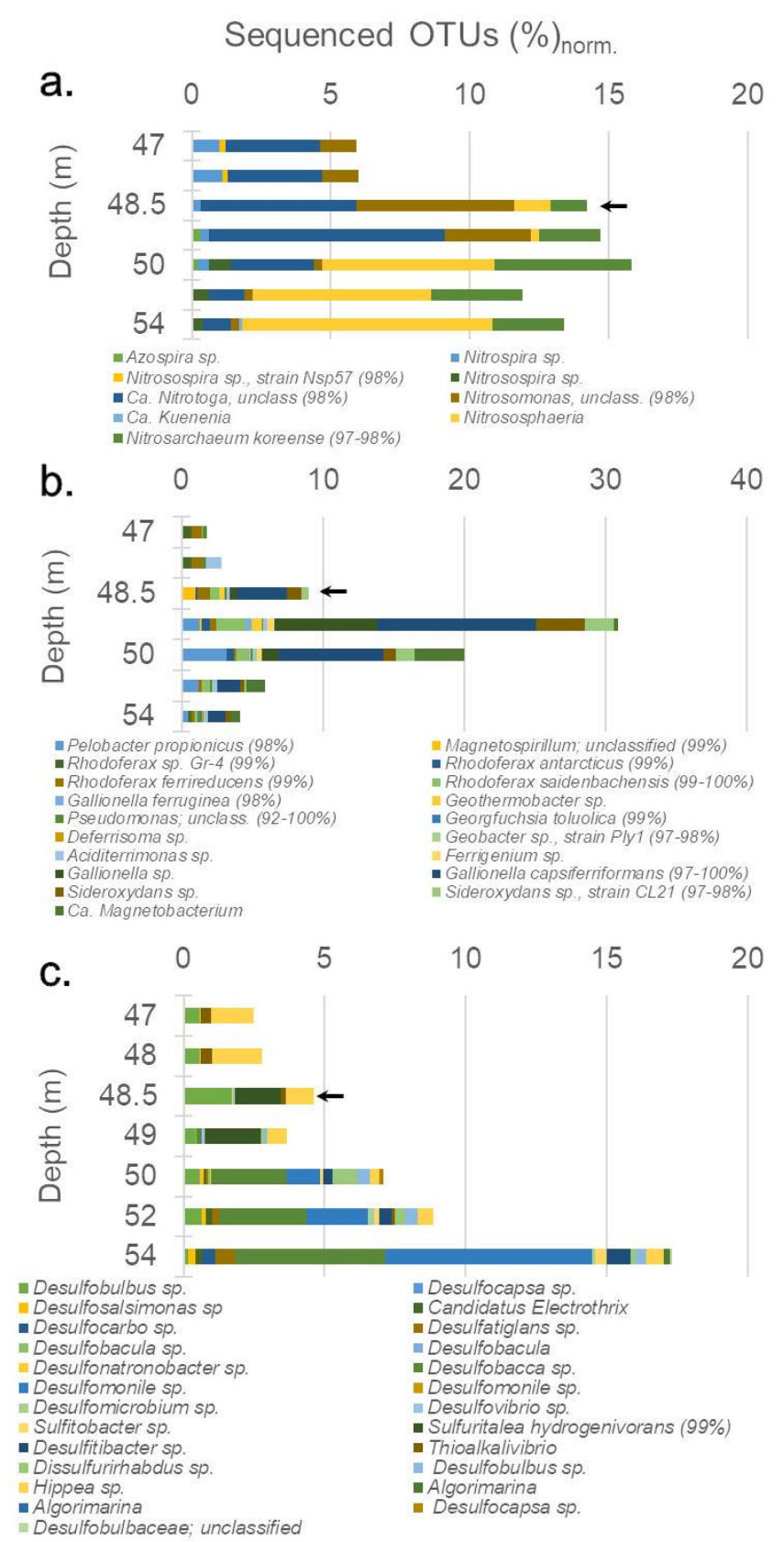

Figure 5. Normalized abundance of nitrogen, iron, and sulfur-utilizing bacteria in the bottom waters of Lake Medard (centre). Sequences were classified based on best BLAST hit results, and putative nitrogen (a), iron (b) and sulfur (c) metabolizing bacteria were identified based on phylogenetic affiliations. Arrow is redoxcline. European Nucleotide Archive (ENA) Sequences were deposited in the EMBL-EBI (PRJEB47217 (from 01.04.2022)).

\subsubsection{Dissolved manganese and iron and the iron- utilizing prokaryotes}

Dissolved manganese concentrations ([Mn]) peaked at about $50 \mathrm{~m}$-depth (Table 1). Below this depth, [Mn] showed a steady decrease (Fig. 4b). This trend indicates that in the water column the $50-\mathrm{m}$ depth acts as a point source of $\mathrm{Mn}(\mathrm{II})$ (Davison, 1993). Fe is also present at a similar concentration magnitude at this depth (Fig. 4b, Table 1), and it can readily act as a reductant of most particulate $\mathrm{Mn}(\mathrm{IV})$ settling down from the mixolimnion (Lovley and Phillips, 1988); Rc. (3):

$$
2 \mathrm{Fe}^{2+}+\mathrm{MnO}_{2}+1.5 \mathrm{H}_{2} \mathrm{O} \rightarrow \mathrm{Fe}_{2} \mathrm{O}_{3} \cdot 0.5 \mathrm{H}_{2} \mathrm{O}+\mathrm{Mn}^{2+}+2 \mathrm{H}^{+}
$$

Accordingly, a significant fraction of the Fe(II) diffusing upwards from the monimolimnion is re-oxidized or cycled back to $\mathrm{Fe}(\mathrm{III})$ within the peak zone of $\mathrm{Mn}(\mathrm{IV})$-reduction at $50 \mathrm{~m}$-depth (Fig. 4b). $\mathrm{Mn}$ (II) yielded during iron oxidation can then be transported both upwards and downwards away from the $50 \mathrm{~m}$-depth source point by eddy diffusion (Fig. 4b; Davidson, 1993). The internal bottom water column cycling of iron also reflects on the concentration gradient of dissolved phosphate (Table 1). Solubilization of this oxyanion in the bottom water

column is regulated by its complexation with particulate $\mathrm{Fe}(\mathrm{III})$ sinks that are in turn being reductively dissolved in the

monimolimnion and SWI. Dissolved phosphate is re-complexed back onto nanocrystalline and amorphous ferrihydrite-like phases precipitating at the redoxcline.

Contrary to $\mathrm{Mn}$, dissolved [Fe] increased steadily downwards, and its global maximum is reached at about $54 \mathrm{~m}$-depth in the monimolimnion (Table 1). Immediately below this depth, $[\mathrm{Fe}]$ decreases by about $14 \%$. This decrease can be consistently 
https://doi.org/10.5194/bg-2021-253

Preprint. Discussion started: 15 November 2021

(c) Author(s) 2021. CC BY 4.0 License.

\section{(c) ${ }_{\mathrm{BY}}$}

observed in other anoxic zones of the lake (Petrash et al., 2018), and hints to Fe(II) and reduced S co-precipitation as metastable acid volatile monosulfide (FeS; e.g., mackinawite). The dissimilar distribution of divalent $\mathrm{Fe}$ and $\mathrm{Mn}$ in the bottom water column (Fig 4 b) reflects reductive dissolution being much more effective for the sinking manganic particulate than for ferric particulate matter.

Our planktonic prokaryote analysis shows that above the redoxcline the diversity of known iron-respiring prokaryotes was low and dominated by species closely related to the $\beta$-Protebacterium Rhodoferax (99-100\% gene similarity) (Fig. 5b, Supplement 2). Other sequences that can be functionally affiliated to Fe(III)-reduction in the dysoxic hypolimnion include a bacterium with some similarity to Aciditerrimonas (91\% similarity), and also operational taxonomic units (OTUs) exhibiting between 92 and 100\% gen similarity to unclassified Pseudomonas spp. (Fig. 5b). Bioutilization of manganese by Pseudomonas species - both in oxidation and reduction reactions - has been reported (e.g., Tebo et al., 2005; Geszvain et al., 2011; Lovley, 2013; Wright et al., 2018).

305 As previously mentioned, we detected a sharp increase in both diversity and abundance of microaerophilic Fe(II)-oxidizing Gallionella species at the redoxcline and immediately below it. It accounted for up to $24 \%$ of the total normalized gene reads (Fig. 5b). The increase in relative abundance of Gallionella spp. coincides with an increase in sequences related to Sideroxydans spp. (Fig. 5b). These latter microaerophiles can also use Fe(II) as an energy source for chemolithotrophic growth with $\mathrm{CO}_{2}$ as the sole carbon source (Emerson and Moyer, 1997). Other different physiological groups of Fe(II)oxidizing microorganisms sequenced above and near-redoxcline samples included anoxygenic phototrophic and nitratereducing species (Magnetospirillum and Ferrigenium; Fig. 5b, Supplement 2), and Azospira-like species.

Prokaryotes that can adapt their metabolic strategies to the less pronounced geochemical gradients prevailing at the monimolimnion become predominant below the redoxcline. Among them is a bacterium distantly related (89\% identity in 399 bp) to Candidatus Magnetobacterium (after Lin et al., 2014), which relative abundance substantially increases at the 50-

$315 \mathrm{~m}$ depth (Fig 5b). At this level, our gene sequence reads also included an OTU distantly related (78\% gene similarity in 419 bp) to Deferrisoma. This genus has been designated as a mixotroph also functionally affiliated to dissimilatory $\mathrm{Fe}(\mathrm{III})$ reduction (e.g., Pérez-Rodríguez et al., 2016), as well as an OTU closely related to Georgfuchsia toluolica. G. toluolica is a

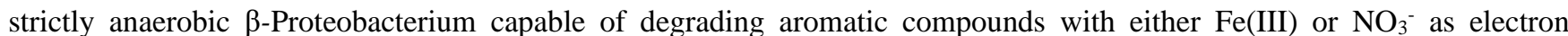
acceptors (Weelink et al., 2009).

320 Towards the SWI, important members of the Fe-respiring community are those from the family Geobacteracea, which can use insoluble $\mathrm{Fe}(\mathrm{III})$ and/or $\mathrm{Mn}(\mathrm{IV})$ as electron acceptors, and acetate, formate, alcohols, aromatics, and dihydrogen $\left(\mathrm{H}_{2}\right)$ as electron donors (Weber et al., 2006; Lovely and Holmes, 2021). The abundance of Geobacter species peaked around the maximum of $\mathrm{Fe}(\mathrm{III})$ reduction within the monimolimnion. Here, acetate availability is also relatively high (Fig. 2b). The relative proportion of Geobacter spp. increases in parallel with that of their phylogenetically associated Pelobacter propionicus, which is a fermentative acetogen that can only indirectly mediate Fe(III) reduction. A possible ecological interaction between $P$. propionicus and Geobacter species at the interface of redox boundaries in sedimentary environments has been already reported by Holmes et al. (2007) and Butler et al. (2009). 
https://doi.org/10.5194/bg-2021-253

Preprint. Discussion started: 15 November 2021

(c) Author(s) 2021. CC BY 4.0 License.

\section{(c) (i)}

\subsubsection{Dissolved sulfate and the sulfur-utilizing prokaryotes}

The dissolved sulfate concentration $\left(\left[\mathrm{SO}_{4}{ }^{2-}\right]\right.$ ) changes significantly at the redoxcline, where it increases from 6.0 to $16.8 \mathrm{mM}$

(Fig. 4c). At the lower monimolimnion, a decrease in $\left[\mathrm{SO}_{4}{ }^{2-}\right]$ coincides with a decrease of [Fe(II)] (Table 1, Fig. 4b-c). We detected an increase in both diversity and relative abundance of sulfate reducers in the lower monimolimnion (Fig. 5c). Their by-product sulfide, however, does not accumulate in the ambient waters $\left(\left[\mathrm{H}_{2} \mathrm{~S}+\mathrm{HS}^{-}\right] \leq 0.30 \mu \mathrm{M}\right)$. The lack of substantial dissolved sulfide towards the SWI and the similar hydrochemical responses of both $\mathrm{Fe}(\mathrm{II})$ and $\left[\mathrm{SO}_{4}{ }^{2-}\right]$ could be considered circumstantial evidence for FeS precipitation. Additional insight on this and other mechanisms of sulfate turnover operating in the water column was sought by evaluating the distribution of S-utilizing prokaryotes.

Our 16S rRNA gene analyses (Fig. 5c; also Supplement 2) revealed a rather low diversity of sulfur-respiring bacteria at the dysoxic hypolimnion. Here OTU assignments show mostly a few uncultured members of the newly proposed order Desulfobulbales of the phylum Desulfobacterota (previously $\delta$-Proteobacteria, Waite et al., 2020; Ward et al., 2021))(Fig. 5c). Some species within Desulfobulbales require intermediate $S$ or thiosulfate for heterotrophic growth but can also gain energy from pyruvate fermentation (Flores et al., 2012). Desulfobulbus spp. can perform dissimilatory sulfate reduction via the incomplete oxidation of lactate, but $D$. propionicus is known for efficiently conducting disproportionation of elemental sulfur (Lovley and Phillips, 1994). Pyruvate, as lactate, was found below our detection limits across the bottom water column where sequences distantly related to D. propionicus (91\% similarity in $428 \mathrm{bp}$ ) appeared to be particularly abundant (Fig. 5c; Supplement 2). Probably important for the microbial sulfur cycling at this level of the water column is also a $\gamma$ Proteobacterium from the order Chromatiales that has $92 \%$ gene identity in 424 bp to Thioalkalivibrio paradoxus (Fig. 5c). T. paradoxus is a chemolithoautotrophic sulfur-oxidizing bacterium that can use both reduced and intermediate $\mathrm{S}$ compounds for $\mathrm{C}$ fixation (Berben et al., 2015).

There are gene sequences that could be confidently ascribed to the facultative S-utilizing autotroph Sulfuritalea hydrogenivorans (3 OTUs with $\geq 97$ identity in $424 \mathrm{bp}$ ) at the redoxcline. The abundance of $S$. hydrogenivorans increases in parallel to a decrease in the T. paradoxus-like bacterium, which suggests that the latter may be at a disadvantage and limited by organic $\mathrm{C}$ fixation under the specific hydrochemical conditions prevailing at the redoxcline. Such conditions may include, for instance, an abundance of aqueous intermediate S species. Under such conditions, S. hydrogenivorans can outcompete the T. paradoxus-like bacterium by oxidizing, under denitrifying conditions, either thiosulfate, $\mathrm{S}^{0}$ and/or $\mathrm{H}_{2}$ for $\mathrm{C}$ fixation (Kojima and Fukui, 2011; Kojima et al., 2014). Interestingly, at the redoxcline, the relative abundance of the species distantly related to fully sequenced Desulfobulbales also increases to $\sim 1.7 \%$ (Fig. $5 \mathrm{c}$ ).

Below the redoxcline, our genomic data revealed successional development of a more diverse sulfur-respiring bacterial population (Fig. 5c). This was dominated by many relatively rare taxa and a few abundant lineages (Supplement 2), and with a punctuated dominance of species distantly related to Desulfobacca acetoxidans (90\% identity in 432 bp). D. acetoxidans oxidizes acetate using either sulfate, sulfite $\left(\mathrm{SO}_{3}{ }^{2-}\right)$ or thiosulfate $\left(\mathrm{S}_{2} \mathrm{O}_{3}{ }^{2-}\right)$ as electron acceptors, but not $\mathrm{S}^{0}$ (Oude Elferink et al., 1999). The D. acetoxidans-like prokaryote first appeared at $49 \mathrm{~m}$ depth but became dominant towards the SWI, together 
https://doi.org/10.5194/bg-2021-253

Preprint. Discussion started: 15 November 2021

(c) Author(s) 2021. CC BY 4.0 License.

\section{(c) (i)}

with Desulfomonile-related species (96\% identity in $432 \mathrm{bp).} \mathrm{Desulfomonile-related} \mathrm{species} \mathrm{could} \mathrm{be} \mathrm{also} \mathrm{responsible} \mathrm{for} \mathrm{the}$ previously noticed pyruvate depletion in the bottom waters, but here they may be also thriving chemolithoautotrophically with either $\mathrm{SO}_{4}{ }^{2-}$ or $\mathrm{S}_{2} \mathrm{O}_{3}{ }^{2-}$ as terminal electron acceptors (DeWeerd et al., 1990; Sun et al., 2001). Other prokaryotes probably gain energy out of intermediate $\mathrm{S}$ disproportionation in the anoxic monimolimnion. These may include uncultured species distantly related to Desulfatibacillum and Dissulfurirhabdus (2 OTUs with $87 \%$ identity in 428 bp). The prevalence of Sulfitobacter across the aqueous redox gradient and into the monimolimnion (Fig. 5c) points to a sustained genetic potential for chemolithotrophic sulfur oxidation in the entire bottom water column.

\section{$4.4 \delta^{34} \mathrm{~S}$ and $\delta^{18} \mathrm{O}$ isotope values of dissolved sulfate}

\subsubsection{Isotopes evidence for disproportionation in the monimolimnion}

370 Water column $\delta^{18} \mathrm{O}_{\mathrm{SO} 4}$ values ranged from +2.0 to $+4.0 \%$, with corresponding $\delta^{34} \mathrm{~S}_{\mathrm{SO}}$ values ranging between +10.9 and $+13.4 \%$ (Table 1, Fig. 6a-b). The depth profiles of these isotopes in the water column reveal that dissolved sulfate in the anoxic monimolimnion is heavier and enriched in ${ }^{18} \mathrm{O}$ (Fig. 6a-b) relative to the dysoxic waters. Despite the moderate decrease in $\left[\mathrm{SO}_{4}{ }^{2-}\right]$ towards the SWI (Fig. 4c) no significant sulfur isotope fractionation was registered. The $\delta^{34} \mathrm{~S}_{\mathrm{SO} 4}$ values (Table 1) display only a weak correlation with $\left[\mathrm{SO}_{4}{ }^{2-}\right]$.

375 The ambient bottom waters had a narrow $\delta^{18} \mathrm{O}_{\mathrm{H} 2 \mathrm{O}}$ signature of $-6.4 \pm 0.3 \%$ (V-SMOW). This is consistent with ongoing meteoric water-rock interactions and rather limited evaporation effects (cf. Noseck et al., 2004; Pačes and Šmejkal, 2004; Dupalová et al., 2012). By applying the expression first proposed by Taylor et al. (1984) to relate the $\delta^{18} \mathrm{O}$ values of dissolved $\mathrm{SO}_{4}{ }^{2-}$ and those of ambient waters, we deduced that the oxygen isotope effect $\left({ }^{18} \varepsilon\right.$ so4-amb. wat. $)$ in our bottom waters ranged between +9.3 and $+10.7 \%$. This range was calculated under the assumption that equilibrium of oxygen isotope exchange between cell-internal sulfur compounds and ambient water dominates over kinetic oxygen isotope fractionation (Fritz et al., 1989; Brunner et al., 2005). The estimated ${ }^{18} \varepsilon_{\text {SO4-amb. wat. }}$ is within the range experimentally derived by Brunner et al. (2005) while using similarly ${ }^{18} \mathrm{O}$-depleted ambient waters. It is also within the range observed in studies of $\mathrm{S}$

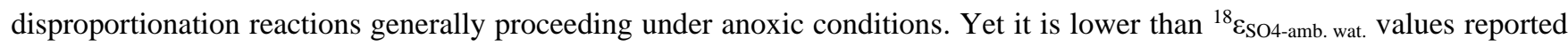
by Bottrell and Newton (2006) in biotic experiments with excess reactive Fe(III) species-i.e., +16.1 to $+17.5 \%$. Therefore,

385 our ${ }^{18} \varepsilon_{\text {SO4-amb. wat. }}$ can result from the superimposition of the isotope signals of sulfate reduction, sulfide re-oxidation and intermediate sulfur disproportionation. It follows that the sulfur disproportionation in the bottom waters of Lake Medard most likely results from multiple biologically mediated reactions involving not only reactive iron, but also reducible Mn stocks in the sediments (Böttcher, Thamdrup and Vennemann, 2001). As further discussed below, the anoxic sediments contain a low- i.e., compared with Fe(III)-counterparts - yet still measurable abundance of Mn(IV)-oxyhydroxides (Table 390 2). 
https://doi.org/10.5194/bg-2021-253

Preprint. Discussion started: 15 November 2021

(c) Author(s) 2021. CC BY 4.0 License.

(c) (i)

A microbially mediated/induced sulfur disproportionation mechanism that considers reactive iron forms present in the sediments, also involves $\mathrm{Mn}(\mathrm{IV}, \mathrm{III})$ reduction, and is consistent with formation of FeS in the monimolimnion can be described by Rs. (4)-(6):

$$
\begin{aligned}
& 3 \mathrm{~S}^{0}+2 \mathrm{FeOOH} \rightarrow \mathrm{SO}_{4}{ }^{2-}+2 \mathrm{FeS}+2 \mathrm{H}^{+} \\
& 4 \mathrm{~S}^{0}+4 \mathrm{H}_{2} \mathrm{O}+3 \mathrm{FeCO}_{3} \rightarrow \mathrm{SO}_{4}{ }^{2-}+3 \mathrm{FeS}+2 \mathrm{H}^{+}+3 \mathrm{H}_{2} \mathrm{CO}_{3} \\
& 3 \mathrm{~S}^{0}+\mathrm{Mn}_{3} \mathrm{O}_{4}+2 \mathrm{H}^{+} \rightarrow \mathrm{SO}_{4}{ }^{2-}+2 \mathrm{HS}^{-}+3 \mathrm{Mn}^{2+}
\end{aligned}
$$

Although not shown in the rather simplified reaction set listed above, $S^{0}$ may well be a different intermediate sulfur species such as thiosulfate and/or sulfite (e.g., Holmkvist et al., 2011). The intracellular isotope exchange of sulfite with anoxic ambient waters has been proven to produce an oxidized $\mathrm{SO}_{4}{ }^{2-}$ product that is enriched in ${ }^{18} \mathrm{O}$ relative to precursory thiosulfate and/or sulfite. This enrichment displays only a minor change, if any, in its corresponding $\mathrm{S}$ isotope composition (e.g., Böttcher et al., 2005; Johnston et al., 2014; Bertran et al., 2020; see Table 1).

\subsubsection{Isotopic insight on intermediate sulfur oxidation}

Figure 6c shows a cross-plot of the $\delta^{34} \mathrm{~S}_{\mathrm{SO} 4} v s . \delta^{18} \mathrm{O}_{\mathrm{SO} 4}$ values along the redoxcline as well as those of all the possible geogenic sources of sulfate entering the lake system (see also Appendix B: Fig. B2). Analysis shows that the $\delta^{34} \mathrm{~S}_{\mathrm{SO} 4}$ values of the redox stratified Lake Medard fingerprint a mixed geogenic-sulfate source. Fig. 6d offers further detail and linear regressions of the covariation in the $\delta^{34} \mathrm{~S}_{\mathrm{SO}} v s$. $\delta^{18} \mathrm{O}_{\mathrm{SO} 4}$ cross-plot. The slopes of such linear regressions can be used to roughly estimate sulfate reduction rates (SRR; after Böttcher et al., 2001; Brunner et al., 2005, among others). For assessing our SRR, it is reasonable to assume that the initial $\mathrm{S}$ and $\mathrm{O}$ isotope composition linked to dissolved sulfate was within the range of the modern nearby acidic drainage (i.e., $+2.9 \pm 0.1 \%$ for $\delta^{34} \mathrm{~S}_{\mathrm{SO} 4}$ and $0.0 \pm 0.5 \%$ for $\delta^{18} \mathrm{O}_{\mathrm{SO} 4}$ ), and similar to the initial composition of sulfate in the pit-lake prior to reclamation/flooding (Fig. 1c-d; also Fig. B2 in Appendix B). The residual isotope composition would then be that of dissolved sulfate in the bottom anoxic waters.

In agreement with the lack of accumulation of sulfide in the monimolimnion, our SRR estimation is consistent with slow gross but not net $\mathrm{SO}_{4}{ }^{2-}$ reduction (see Böttcher et al., 2004). The SRR estimate is apparently slower at the monimolimnion (i.e., higher slope) than in the hypolimnion. This is at odds, however, with the higher abundance and diversity of sulfate

415 reducers that we detected near the SWI (Fig. 5c). The decrease in dissolved sulfate concentration does not lower the slope of the linear regression. It means that the sulfur isotope ratio of dissolved sulfate evolves slower relative to corresponding change in oxygen isotope ratio (Antler et al., 2013). This result is likely due to sulfate regeneration through microbial sulfide oxidation; with oxygen isotope exchange with ambient water occurring via an intracellular oxidation step of intermediate sulfur (Böttcher et al., 2005; Bertran et al., 2020). Under the low organic substrate availability characterizing the bottom waters examined here (Fig. 2b), sulfate reducers capable of disproportionation (e.g., bacteria from the order Desulfobulbales) 
https://doi.org/10.5194/bg-2021-253

Preprint. Discussion started: 15 November 2021

(c) Author(s) 2021. CC BY 4.0 License.

(c) (i)

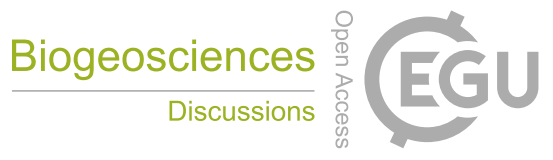

can maintain intracellular concentrations of sulfite. This manifested geochemically as the rapid change in water column $\delta^{18} \mathrm{O}_{\mathrm{SO} 4}$ (Böttcher et al., 2005; Antler et al., 2013).
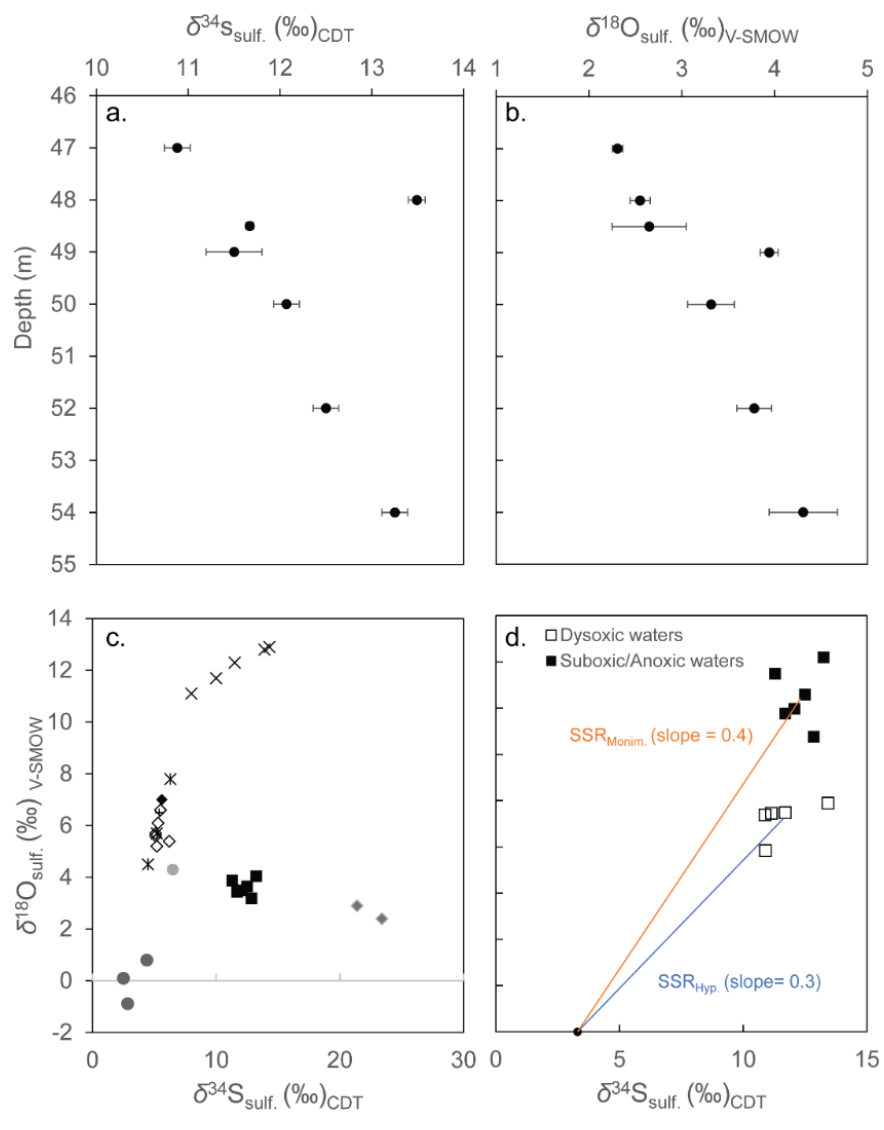

४ Sulfate from weathered pyrite-rich sands

* Thenardite crusts

- Sulfate from compact claystones

$\diamond$ Gypsum laminae

+ Gypsum filling cross-joints

- Gypsum associated with ooliths

- Bottom suboxic/anoxic waters of the post-mining lake

Figure 6. The bottom water column $\delta^{18} \mathrm{O}_{\text {sO4 }}$ and $\delta^{34} \mathrm{~S}_{\mathrm{SO}} 4$ values (a-b). Also, a cross-plot of these values in the water column vs. those of all possible sources of dissolved $\mathrm{SO}_{4}{ }^{2-}$ to the modern lacustrine system (c). The coupled sulfur and oxygen isotope-constrained slopes of the linear regressions provide a rough estimation of the SRR. The regressions considered the $\delta^{18} \mathrm{O}_{S 04}$ and $\delta^{34} \mathrm{~S}_{\mathrm{SO}}$ of the acidic drainage as the initial isotope composition of dissolved sulfate immediately after flooding (see text for details).

\subsection{Insights from solid phase analyses}

\subsubsection{Semi-quantitative $X$-ray diffraction}

430 XRD analyses of the anoxic sediments show that most detrital minerals were sourced from the Miocene claystone lithology (Appendix A). These detrital phases include kaolinite, quartz, $\mathrm{K}$-feldspar, the $\mathrm{TiO}_{2}$ polymorphs rutile and anatase, and analcime $\left(\mathrm{NaAlSi}_{2} \mathrm{O}_{6} \cdot \mathrm{H}_{2} \mathrm{O}\right)$. Minor constituents of the anoxic lake sediments that can also be quantified include gypsum, siderite, and pyrite. Gypsum and siderite are in similar abundances in the upper anoxic sediments ( 3 to 4 wt. \%), whereas 
https://doi.org/10.5194/bg-2021-253

Preprint. Discussion started: 15 November 2021

(c) Author(s) 2021. CC BY 4.0 License.

pyrite accounts for a maximum of $0.5 \mathrm{wt}$. \% of their total mineralogy (Fig. 7a). Given that the diffraction peaks of major and minor mineral sediment constituents mask those of Fe(III)- and Mn(IV)-oxyhydroxides, the abundances of these reactive phases were determined through a sequential extraction scheme that also targets Fe(II)- and Mn(II)-bearing carbonates.

\subsubsection{Sequential extractions of reactive iron}

Figure $7 \mathrm{~b}$ displays the relative concentrations of highly reactive Fe-bearing species $\left(\mathrm{Fe}_{\mathrm{HR}}\right)$ in the upper anoxic sediment pile. The $\mathrm{Fe}_{\mathrm{HR}}$ sediment pool is defined as that capable of reacting (upon reductive dissolution) with dissolved sulfide to precipitate metastable FeS, which can later be stabilized to pyrite (Canfield and Berner, 1987; Canfield, 1989). We also report here $\mathrm{Fe}(\mathrm{II})$ bound to the pyrite fraction $\left(\mathrm{Fe}_{\mathrm{py}}\right)$, and the total iron $\left(\mathrm{Fe}_{\mathrm{T}}\right)$ in the sediments (after Poulton and Canfield, 2005).

Our $\mathrm{Fe}_{\mathrm{HR}}$ was dominated by poorly crystalline phases (Feh), such as ferrihydrite and/or lepidocrocite $(\gamma$-FeOOH). These $\mathrm{Fe}_{\mathrm{HR}}$ mineral fractions were followed in abundance by that of Fe(II)-bearing carbonates (FeC) (Fig. 7b, Table 2). Absolute

$445 \mathrm{Fe}(\mathrm{III})$ concentrations ascribed to Feh phases increase slightly towards the bottom of our $8 \mathrm{~cm}$ depth core but their abundance, relative to total iron, decreases downwards. The extraction step for Feh also extracts Fe(II) bound to FeS (Kostka et al., 1995; Scholz and Neumann, 2007). These metastable phases yielded $\leq 0.04 \mathrm{wt}$. \% according to our acid volatile sulfur (AVS) extraction. However, during sampling of the sediments possible rapid oxidation of AVS particles makes it challenging to assess their actual abundance and mineralogy (Schoonen, 2004). It thus appears then that the Feh abundance

450 at the top of the sediments (Fig. 7b) is mostly comprised of poorly crystalline oxyhydroxide.

A significant increase in the $\mathrm{FeC}$ is observed with increasing depth (Table 2; Fig. 7b). This may be indicative of partial dissolution of some Fe(II)-bearing carbonates at the SWI, or the result of soluble Fe(II) being precipitated into reactive Fecarbonates deeper through the sedimentary pile. To clarify this matter, we discuss the petrographic features and $\mathrm{C}$ isotope values of these sedimentary siderites in Sect. 4.6.3.

Table 2. Partitioning of reactive iron and manganese species in the lacustrine sediments $(0-8 \mathrm{~cm}$ depth).

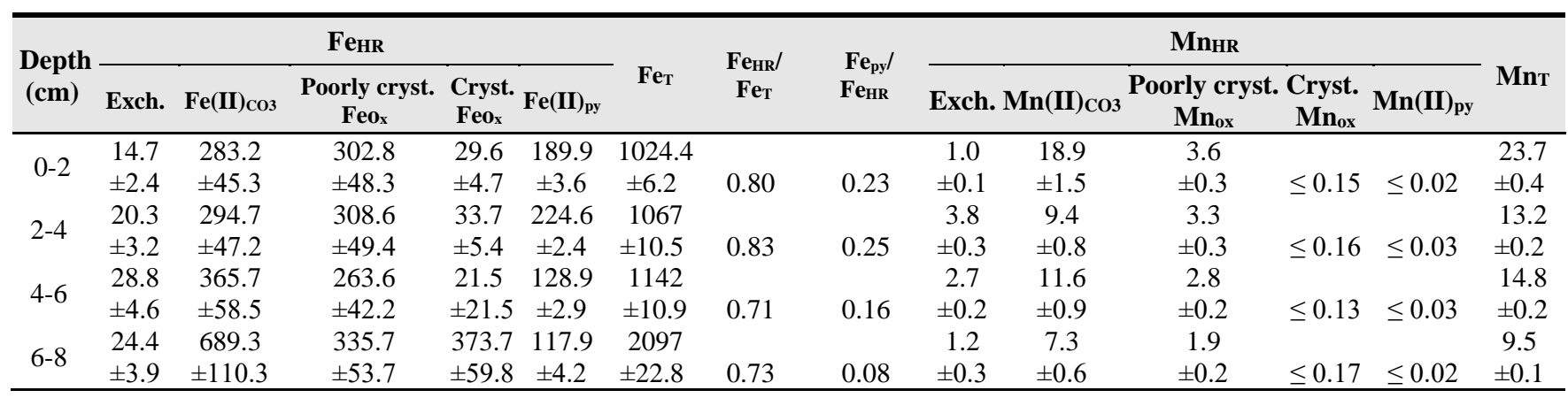

\# Sediment density is estimated in $2.71 \mathrm{~g} \cdot \mathrm{L}^{-1}$ with a porosity of $40 \%$; error of the measurement $(\mathrm{n}=4)$ is $\pm 16 \%[\mathrm{Fe}]$ and $\pm 8 \%[\mathrm{Mn}]$; in $\mu \mathrm{mol} \cdot \mathrm{cm}{ }^{-3}$. 
https://doi.org/10.5194/bg-2021-253

Preprint. Discussion started: 15 November 2021

(c) Author(s) 2021. CC BY 4.0 License.

The iron extracted from crystalline Fe(III)-bearing phases (such as goethite) increased from $2.7 \pm 0.4 \%$ in the first $6 \mathrm{~cm}$ to up to $17.8 \%$ of the $\mathrm{Fe}_{\mathrm{T}}$ at the 6 to $8 \mathrm{~cm}$ interval (Table 2). Fe concentrations bound to pyrite (Table 2, Fig. 7b) constituted up to $\sim 21 \%$ of the $\mathrm{Fe}_{\mathrm{T}}$ in the upper sediments (i.e., $\sim 0.8 \mathrm{wt} . \%$ ), and showed a general downwards decreasing trend contrasting

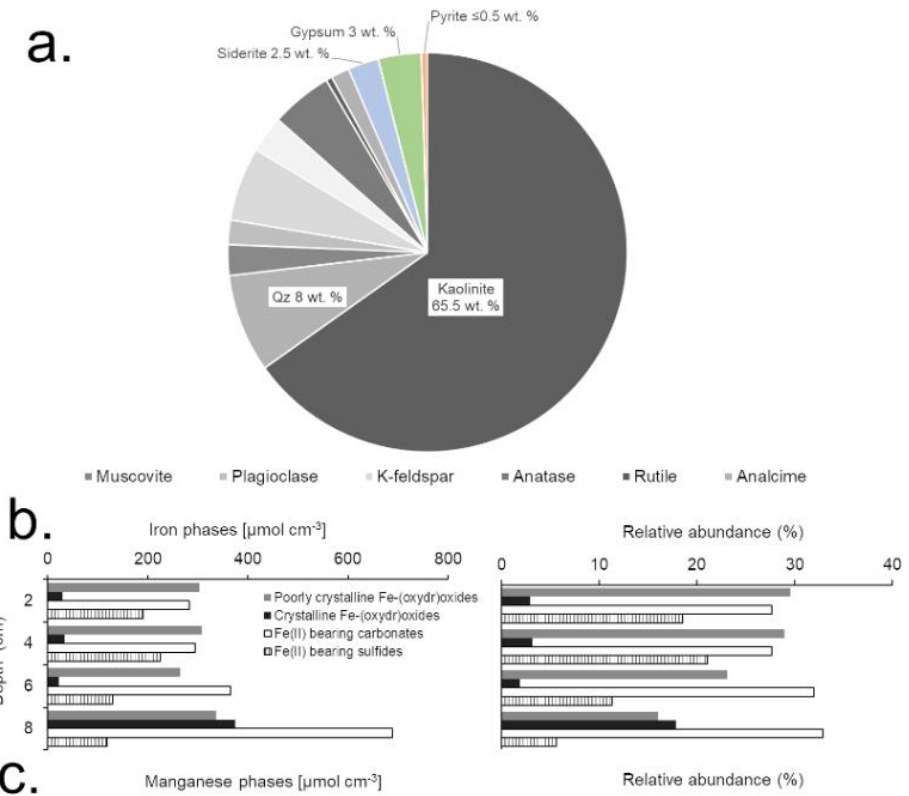

C. Manganese phases $\left[\mu \mathrm{mol} \mathrm{cm}^{-3}\right.$
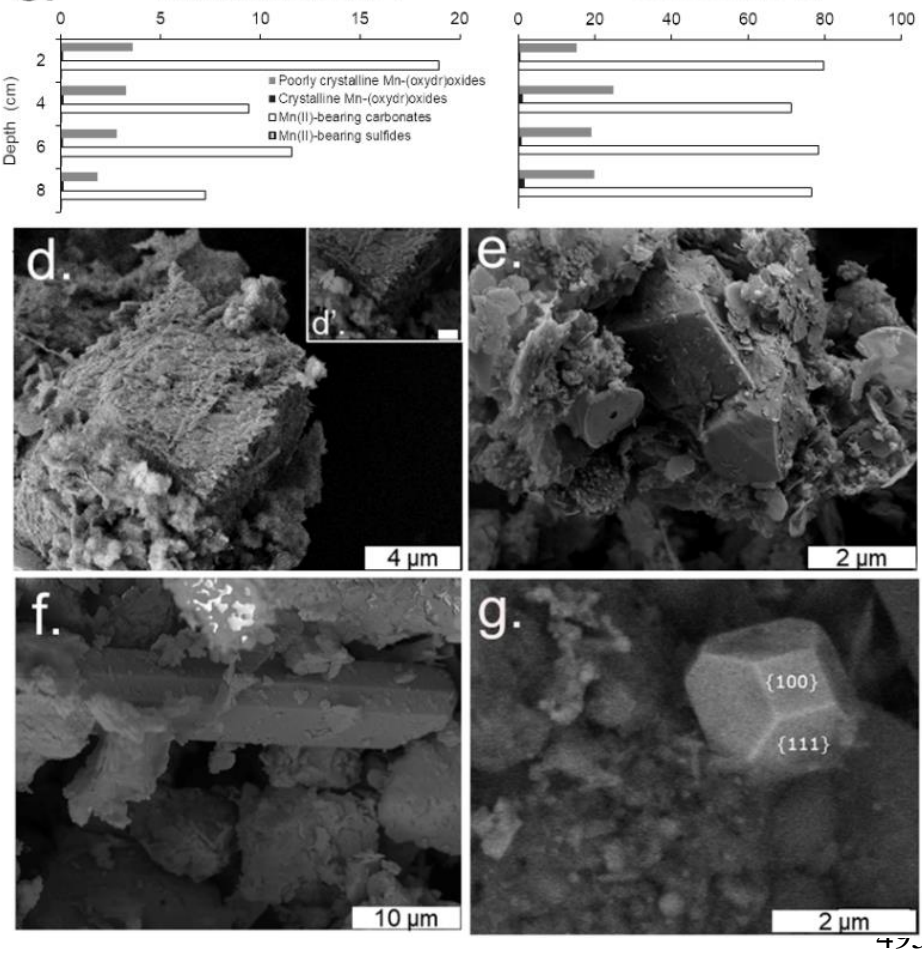

with that of that of crystalline $\mathrm{Fe}(\mathrm{III})$-bearing phases. From these observations, the 0 to $6 \mathrm{~cm}$ depth interval is considered as recent anoxic lake deposition, whilst below $6 \mathrm{~cm}$ are sediments that were deposited in the shallow pit lake now undergoing alteration under the redox dynamics of the present-day lacustrine system.

The $\mathrm{Fe}_{\mathrm{Py}} / \mathrm{Fe}_{\mathrm{HR}}$ ratio in the $8 \mathrm{~cm}$ sediment profile accounts for the extent to which the Fe pool was pyritized. The ratio is $<0.35$ and it decreases downwards (Table 2). When considering that the corresponding $\mathrm{Fe}_{\mathrm{HR}} / \mathrm{Fe}_{\mathrm{T}}$ ratios were consistently $\geq 0.71$, the results from our sequential extraction scheme applied to iron are consistent with a persistent ferruginous but not euxinic redox state of the now anoxic sediments (Poulton and Canfield, 2011). Variability of $\mathrm{Fe}_{\mathrm{py}} / \mathrm{Fe}_{\mathrm{HR}}$ and $\mathrm{Fe}_{\mathrm{HR}} / \mathrm{Fe}_{\mathrm{T}}$ with depth of the sediments reflects the redox dynamics after flooding and establishment of a persistently anoxic monimolimnion.

Figure 7. Mineralogical analyses of the upper sediment ( 0 to $8 \mathrm{~cm}$ depth), the semi-quantitative XRD data (a) shows that the sediments are dominated by aluminosilicates and contain pyrite, gypsum, and siderite. Results from sequential extraction of iron (b) and manganese (c) portray changes in partitioning of these metals in reactive oxyhydroxide, carbonate and sulfide solid phases with increasing sediment depth. SEM-EDX of rhombohedral siderite in the 0-4 (d) and 4-8 cm sediment depth intervals (e). This carbonate mineral displayed corroded surfaces near the sedimentwater interface. The texture of microcrystalline equant gypsum (f) and truncated octahedral microcrystalline pyrite (g) are also shown (see text for details).

From combining results from $\mathrm{Fe}_{\mathrm{HR}}$ partitioning in the sediments (Table 2) and the dissolved $\mathrm{Mn}$ (II) and Fe(II) concentration trends (Fig. 4b), we can now strengthen an earlier deduction that $\mathrm{Fe}(\mathrm{II})$ sourced from reductive 
https://doi.org/10.5194/bg-2021-253

Preprint. Discussion started: 15 November 2021

(c) Author(s) 2021. CC BY 4.0 License.

\section{(c) (i)}

dissolution processes in the upper sediments diffuses upwards, where it rapidly reacts with residual $\mathrm{O}_{2}$ in the vicinity of the redoxcline to form metastable Fe(III)-bearing particulate phases. Most of the iron in such amorphous to nanocrystalline ferrihydrite-like aggregates are deposited on the lake's anoxic floor. From the anoxic floor they are resolubilized back into the monimolimnion, yet a significant fraction can stabilize upon burial as goethite $(\alpha-\mathrm{FeOOH})$ or be bound to the surfaces of reactive carbonates. Another fraction is pyritized through reactions involving elemental sulfur and/or polysulfide near the sediment-water interface (Fig. 7b) (see Shoonen, 2004 for details). Indeed, we observed that in the upper sediment the partitioning of the reactive iron into these minerals can be swiftly altered by slight $( \pm 80 \mathrm{mV})$, short-lived variations in the redox potential of the overlying bottom water column. Variations in the relative proportions of reactive iron minerals also control the distribution of siderophile redox sensitive elements in the sediment pile (Umbria Salinas et al., 2021).

\subsubsection{Sequential extractions of reactive Mn-bearing phases}

Results from our extraction scheme applied to Mn (i.e., after Slomp et al., 1997; Van Der Zee and Van Raaphorst, 2004) show that the $\mathrm{Mn}_{\mathrm{HR}}$ pool in the anoxic sediment was dominated by Mn(II)-bearing carbonates (MnC) (Fig. 7c, Table 2). The carbonates were relatively more abundant at the SWI but in contrast to $\mathrm{FeC}$, showed no clearly defined concentration trend in the upper sediments (Table 2, Fig. 7b-c). A declining trend downwards is clear for the proportions of easily reducible $\mathrm{Mn}\left(\mathrm{IV}\right.$ )-bound to poorly crystalline phases, such as $\delta-\mathrm{MnO}_{2}$. These were extracted by diluted $\mathrm{HCl}$ (Fig.7c, Table 2) (Slomp et al., 1997). Reducible Mn associated with more crystalline oxyhydroxide forms are extracted by dithionite (Canfield et al., 1993), but concentrations of this fraction might be sourced from crystalline Fe(III)-oxyhydroxides that can either sorb Mn(II) or structurally incorporate Mn(III) (Namgung et al., 2020). Irrespective of its source, the highly crystalline Mn-bearing fraction in our sediment comprises $\leq 0.2$ wt. $\%$ of $\mathrm{Mn}_{\mathrm{T}}$ (Table 2). The concentrations of $\mathrm{Mn}$ (II) bound to sulfides accounted for $\leq 0.03$ wt. $\%$ of the total Mn extracted (Fig. 7c, Table 2). From the analyses of the partitioning of reactive Mn species, we can thus confirm that under the anoxic conditions currently prevailing in the bottom waters and SWI of Like Medard, a minor, yet still important fraction of reducible $\mathrm{Mn}_{\mathrm{HR}}$ can be exported from the water column, and can participate, together with the reactive forms of iron, into the internal cycle of S (e.g., reaction 6).

\subsection{Insights from siderite, gypsum, and pyrite analyses}

520 Siderite accounts for up to $3.5 \mathrm{wt}$. \% of the total mineralogy of the anoxic lacustrine sediment where it occurs as dispersed fine crystalline rhombohedra (Fig. 7d-e). Siderite displays corroded surfaces towards the SWI. This textural feature cannot be observed in crystals at the 4 to $8 \mathrm{~cm}$ depth interval. This is consistent with results from the sequential iron extraction scheme (see above) indicative of Fe-carbonate likely undergoing recrystallization and/or growth in the deeper part of the examined sediment pile but partial dissolution towards the SWI in spite of its low supersaturation in the monimolimnion waters $\left(\Omega_{\text {sid. }}=\log\right.$ IAP $\cdot\left(\log \mathrm{K}_{\mathrm{SP}}\right)^{-1}=1.8$; Supplement 3$)$.

The siderite is enriched in ${ }^{13} \mathrm{C}$ by around $+9 \%$ (mean $\delta^{13} \mathrm{C}$ value of siderite is $+6.4 \pm 0.3 \%$ ) relative to $\Sigma \mathrm{CO}_{2}$ of the bottom water column (Table 1). The mean $\delta^{13} \mathrm{C}$ value is, however, within the range of $\delta^{13} \mathrm{C}$ isotope values reported by Šmejkal 
https://doi.org/10.5194/bg-2021-253

Preprint. Discussion started: 15 November 2021

(c) Author(s) 2021. CC BY 4.0 License.

\section{(c) (i)}

(1978) for carbonates of the Cypris claystone. Also, the mean $\delta^{18} \mathrm{O}$ (SMOW) values $(+25.7 \pm 1.7 \%$ o) of siderite are within the range observed in Miocene carbonates which, in addition to siderite, include also dolomite and calcite (Šmejkal, 1978, 1984). From combining the average isotopic values and textural features of siderite in our anoxic sediments, the mineral can then be considered a seeded (detrital) phase also sourced from the Cypris claystone. Siderite seeds were probably redeposited in the floor of the post-mining lake, together with aluminosilicates and other major and minor phases, during the lake's flooding stage (2008-2015) or thereafter.

Gypsum has a relative abundance of $c a .3$ wt. \%. It displays a microcrystalline $\{010\}$-dominated platy shape (Fig. 7f). This is an equilibrium morphology corresponding to a rather low supersaturation (e.g., Simon et al., 1965; van der Voort and Hartman, 1991; Massaro et al., 2010; Rodríguez-Ruiz et al., 2011). This soluble mineral is not thermodynamically stable by the aqueous-mineral equilibrium modeling of the monimolimnion water (i.e., $\Omega_{\mathrm{gy}}=-0.5$; Supplement 3 ). However, at a low supersaturation state $\left(0<\Omega_{\mathrm{gy}}<1\right)$, gypsum would be formed within the upper sediment pore spaces where $\mathrm{Ca}^{+2}$ ion concentrations are increased locally, for instance by carbonate dissolution.

540 Gypsum precipitation under low saturation states can probably occur as the result of short-lived, climatically constrained changes in the precipitation-dissolution environment of carbonates in the upper sediment pile (see Umbria-Salinas and Valero et al., 2021). The isotope values of the sulfate moiety in the authigenic gypsum $\left(\delta^{34} \mathrm{~S}_{\mathrm{gy}}\right.$ and $\left.\delta^{18} \mathrm{O}_{\mathrm{gy}}\right)$ provide further insight on the significance of this phase within the internal sulfur cycle and early diagenetic context of the system under consideration. The $\delta^{34} \mathrm{~S}_{\mathrm{gy}}$ isotope values ranged from -13.9 and -9.6\% (V-CDT). Accordingly, gypsum shows ${ }^{34} \mathrm{~S}$-depletion of -17.8 to $-11.6 \%$ relative to dissolved $\mathrm{SO}_{4}{ }^{2-}$ in the ambient anoxic waters (Table 1). The $\delta^{18} \mathrm{O}_{\mathrm{gy}}$ values range from +5.1 to $+6.3 \%$ (V-SMOW). In consequence, the sulfate in gypsum is enriched by +1.4 to $+2.6 \%$ as ${ }^{18} \mathrm{O}$ compared with the mean $\delta^{18} \mathrm{O}_{\mathrm{SO} 4}$ of the monimolimnion (Table 1). This magnitude of isotope ${ }^{18} \mathrm{O}$ enrichment of gypsum-sulfate appears consistent with the range observed when sulfate is derived from pyrite that is oxidized by ferric iron in aqueous anaerobic experiments (e.g., Taylor et al., 1984b; Toran and Harris, 1989; Balci et al., 2007).

550 A net $\mathrm{O}_{2}$ neutral reaction that also accounts for (i) significant monosulfide oxidation, (ii) the localized presence of corroded siderite in the upper sediment, (iii) involves chemolithoautotrophic fixation of $\mathrm{CO}_{2}$, and (iv) produces an isotopically light gypsum-sulfate, could therefore be written (Rc. 7):

$$
3 \mathrm{Fe}^{32} \mathrm{~S}+3 \mathrm{CaCO}_{3}+\mathrm{FeCO}_{3}+14 \mathrm{H}_{2} \mathrm{O} \rightarrow 4 \mathrm{FeOOH}+3 \mathrm{Ca}^{32} \mathrm{SO}_{4} \cdot 2 \mathrm{H}_{2} \mathrm{O}+4 \mathrm{CH}_{2} \mathrm{O}
$$

Reaction 7 assumes that the acidity produced by the oxidation of pyrite and its precursors is neutralized by a 3:1 dissolution of calcium to iron carbonate phases in the upper anoxic sediments. The $\mathrm{Ca}^{2+}$ ions released by carbonate dissolution can then co-precipitate with the porewater $\mathrm{SO}_{4}{ }^{2-}$ ions to form gypsum. The mineral is ${ }^{34} \mathrm{~S}$-depleted as compared to sulfate dissolved in the monimolimnion but it reflects the $\delta^{18} \mathrm{O}$ signature of the ambient water; with an equilibration effect (i.e., $\varepsilon^{18} \mathrm{O}_{\text {sO4-amb.water }}$ ) which, as mentioned above, ranges between +9.3 and $+10.7 \%$.

Pyrite accounted for $\leq 0.5$ wt. \% of the total XRD-estimated mineralogy of the sediments and occurs as finely dispersed single octahedral crystals that are up to $2 \mu \mathrm{m}$ in size, and exhibit $\{111\}$ and $\{100\}$ truncations (Fig. $7 \mathrm{~g}$ ). This morphology is 
https://doi.org/10.5194/bg-2021-253

Preprint. Discussion started: 15 November 2021

(c) Author(s) 2021. CC BY 4.0 License.

(c) (i)

often seen to develop under sulfide-limited conditions in synthetic experiments (e.g., Barnard and Russo, 2009). From the morphology of pyrite and because its $\delta^{34} \mathrm{~S}$ isotope signature differs considerably from those of weathered pyrite in the coal seams-associated lithology (Bouška et al., 1997; Appendix B: Fig B2), this mineral is more probably authigenic in origin. It must have formed locally within the anoxic sediments at low supersaturation, and with nucleation itself depleting the availability of reactants (i.e., $\mathrm{S}_{2}{ }^{2-}$ species) required for further nuclei formation (Rickard and Morse, 2005). Thus, its dispersed, fine crystalline occurrence.

The $\delta^{34} \mathrm{~S}$ isotope values of the finely dispersed pyrite crystals are operationally defined as those of the bulk sediment chromium-reducible sulfide (CRS) pool (i.e., after Canfield et al., 1986). In the upper anoxic sediments, this CRS pool became ${ }^{34} \mathrm{~S}$-enriched with depth. Accordingly, in the 0 to $4 \mathrm{~cm}$-depth pyrite has $\delta^{34} \mathrm{~S}_{\mathrm{CRS}}$ isotope values of $-34.7 \pm 0.4 \%$. At 4 to $8 \mathrm{~cm}$ sediment depth, however, it is relatively ${ }^{34} \mathrm{~S}$-enriched $\left(\delta^{34} \mathrm{~S}_{\mathrm{CRS}}=-23.9 \pm 0.9 \%\right)$. Pyrite captures the isotopic signature of dissolved sulfide in its local precipitation environment, and at and near the SWI this mineral appears to have recorded an isotopic offset $\left({ }^{34} \varepsilon \mathrm{CRS}-\mathrm{SO} 4\right)$ of around $38 \%$ relative to the $\delta^{34} \mathrm{~S}_{\mathrm{SO} 4}$ of the monimolimnion. This magnitude of fractionation in pyrite could be ascribed to incomplete microbial sulfate reduction) also perhaps with an additional open system oxidative sulfur cycling (Johnston et al., 2005, Zerkle et al., 2010), and it may point to our biogenic pyrite results from the activity of bacteria capable of fully oxidizing the organic substrates scarcely available (Canfield, 2001; Brüchert, 2004). This explains the observed depletion of lactate and pyruvate at this depth in the water column. Limited microbial sulfate reduction is consistent with the fact that pyrite in the lacustrine sediments under consideration precipitates without triggering quantitative sulfate exhaustion (Scholz, 2018; Canfield, 2001)

Approximately $10 \%{ }^{34} \mathrm{~S}$ isotope enrichment in authigenic pyrite at the bottom of our section hints to an additional heavy 580 CRS formation mechanism being more active deeper within the anoxic sediment pile. It could also be the case that the $\delta^{34} \mathrm{~S}_{\mathrm{SO} 4}$ values in porewaters in equilibrium with the heavier pyrite are evolved because of variable fractionations associated with MSR (Canfield, 2001; Brüchert, 2004). The $\delta^{34} S$ values of pyrite from the lower part of the cores also exhibit a narrower difference when compared with those of coexisting authigenic gypsum as shown in Fig. B2 (Appendix B). We can attribute these results to a greater abundance of highly reactive Feh phases capable of oxidizing monosulfide (Table 2) in the lower part of the cores investigated.

The CRS pool also includes the sediments' $S^{0}$ fraction (Canfield et al., 1986), and given that $S^{0}$ derived from the chemolithotrophic oxidation of sulfide is relatively ${ }^{34}$ S-enriched (e.g., Zerkle et al., 2016; Pellerin et al., 2019), we suggest that the ${ }^{34} \mathrm{~S}$ enrichment in the bottom sediments fingerprints the incorporation of some isotopically heavier $S^{0}$ into the CRS pool. This interpretation is not only consistent with the decreased proportions of $\mathrm{Fe}_{\mathrm{Py}}$ in the lower part of the sediment pile (Table 2), but also with microbial disproportionation-induced fractionation (e.g., Pellerin et al., 2019). 
https://doi.org/10.5194/bg-2021-253

Preprint. Discussion started: 15 November 2021

(c) Author(s) 2021. CC BY 4.0 License.

(c) (i)

\subsection{Perspectives for deep time palaeoceanographic and/or diagenetic interpretations}

The redox stratified bottom waters of Lake Medard demonstrate that ferruginous conditions can develop without substantial sulfate consumption (Scholz, 2018, and references therein). The current lake system thus provides the opportunity to investigate biogeochemical controls active under a transitional state between nitrogenous and sulfidic conditions. This state has not been observed in the scarce examples of redox stratified marine basins existing today (Lyons et al., 2009), nor in the few natural mesotrophic to eutrophic meromictic lakes also used as analogues for disentangling redox boundary conditions in ancient oceans. Similar transitional states would have been more prevalent at times with decreased seawater sulfate concentrations and diminished shuttling of Fe(II) to sediments. Together these factors would have enabled more widespread Phanerozoic ferruginous conditions (Reershemius and Planavsky, 2021) that at times also encompassed the water column of epicontinental seas (e.g., Petrash et al., 2016).

The link between the biogeochemical controls operating in the water column of our study site and the mineral equilibrium conditions prevailing near and at its anoxic SWI may also be relevant for studying elusive shallow burial diagenetic signals developed in fluid-buffered sediments. Also, to unravel long-term overprinting of redox proxies in carbonates altered in movable redox stratified coastal aquifers (Petrash et al., 2021).

605 In deeper geological time, the increased delivery of continental sulfate to Precambrian sediments containing not only iron oxyhydroxides but also siderite, probably triggered early diagenetic reactions similar to those reported here (e.g., Bachan and Kump, 2015). Comparable diagenetic hydrochemical conditions would have arisen as well when transgressions of basinal ferruginous seawater affected evaporitic facies buried by coastal progradation. In this scenario, the low preservation potential of gypsum would have hindered direct interpretations of any possible isotopic offset recorded by its more stable replacive phases (e.g., silicified calcite or dolomite).

Although gypsum is rarely preserved in Proterozoic shallow-marine successions (but see Blättler et al., 2018), pseudomorphic carbonates after this mineral are volumetrically important in many Precambrian peritidal facies. In such facies, primary gypsum was often replaced by a metastable early diagenetic phase (e.g., Philippot et al., 2009). In a modern thrombolite-forming environment, Petrash et al. (2012) describes an early replacement process of gypsum that involves

615 initial replacement by metastable aragonite. This produces $\mathrm{Sr}$ carbonate signals in pseudomorphic calcite replacing aragonite that depart from the $\mathrm{Sr}$ content of the ambient water, and, by analogy, can disguise an ancient primary gypsum mineralogy. Similarly to $\mathrm{Sr}$, the structurally substituted sulfate in the carbonate lattice (CAS) of peritidal carbonates (i.e., as a putative proxy for contemporary Proterozoic seawater sulfate) can also be altered early during diagenesis, and exhibit isotope signals incompatible with those of coexisting pyrite (Blättler et al., 2020). This the $\delta^{34} \mathrm{~S}$ signatures of these phases-if formed contemporaneously — shall be expected to approach one each other as per the low dissolved sulfate levels generally ascribed to Proterozoic oceans (e.g., $<400 \mu \mathrm{M}$, Fakhraee et al., 2019). An explanation for such a discrepancy is that the CAS and pyrite $\mathrm{S}$ isotope proxies recorded the pore fluid signal of diagenetically evolved sulfate in Precambrian (e.g., Rennie and Turchyn, 2014; Li et al., 2015), and some Phanerozoic (e.g., Thomazo et al., 2019) evaporitic/stromatolitic facies 
https://doi.org/10.5194/bg-2021-253

Preprint. Discussion started: 15 November 2021

(c) Author(s) 2021. CC BY 4.0 License.

(c) (i)

Conversely, a similar inconsistency could arise when early diagenesis ensued transient out-of-equilibrium water column conditions equivalent to those currently prevailing in Lake Medard, where dissolved $\mathrm{Fe}^{2+}$ is the dominant redox species, substantial dissolved and solid phase sulfate are present, and the upper stocks of $\mathrm{Fe}_{\mathrm{HR}}$ effectively buffer dissolved sulfide accumulation.

\section{Conclusions}

We investigated biomineralization reactions occurring, and prokaryotes thriving in the ferruginous and sulfate-rich bottom 630 water column of a post-mining lake. For this purpose, we considered the pools and fluxes of iron, manganese, carbon, nitrogen, and sulfur in the bottom redox stratified water column and upper reactive sediments (Fig. 8). Discrete spectroscopic datasets were combined with a 16S rRNA gene-aided inference of the planktonic prokaryote community structure to unravel the mechanisms procuring and/or consuming bioactive nitrogen, iron, and sulfur species in the redox stratified ecosystem. Integration of these datasets provides evidence for niche differentiation, but despite marked redox gradients in the water column, we observed a sustained genetic potential for anoxygenic sulfide oxidation and intermediate sulfur disproportionation. The processes were further substantiated by using sulfate $\mathrm{S}$ and $\mathrm{O}$ isotope systematics as summarized in Fig. 8. Microbe-mineral interactions near the anoxic sediment-water interface near the anoxic sediment-water interface modulate the aqueous equilibrium of both reactive authigenic and redeposited Fe- and Mn-bearing phases. A vigorous anoxic sulfide oxidation pathway is coupled to the reduction and solubilization of the ferric and manganic particulate stocks

640 of the lacustrine sediment (Fig. 8).

Dissolved sulfate need not to be quantitatively depleted for the establishment of ferruginous conditions in the water column. The aqueous system-scale reactions currently proceeding in the redox stratified water column and upper anoxic sediments of Lake Medard are relevant for describing transient redox imbalanced stages between nitrogenous and ferruginous conditions that developed in water columns of ancient nearshore marine settings featuring decreased but not exhausted sulfate levels.

645 These could have produced some of the conflicting signatures often described for coexisting phases of interest as peleoredox proxies, e.g., carbonates and sulfides. The effects in the geochemical record of analogue imbalanced states are yet to be fully accounted for. This research effort has implications for untangling the deep time palaeoceanographic redox structure of continental margins. We anticipate that further studies in the ferruginous artificial lacustrine system targeted here can provide a more complete picture depicting processes recorded by conflicting proxies in several key, well-preserved Precambrian shallow marine facies. 


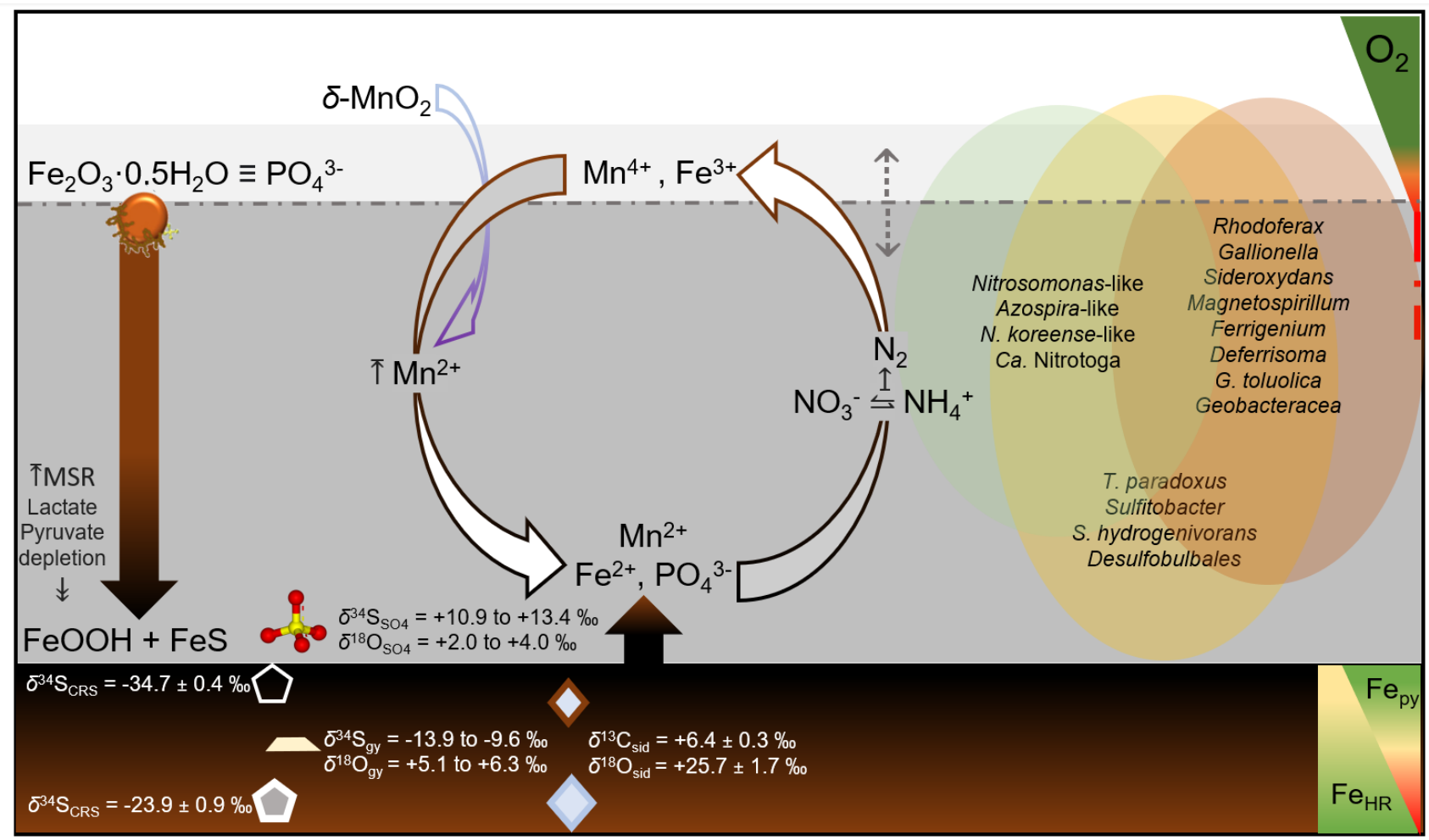

Figure 8. Scheme summarizing the speciation and stable isotopes ranges of sulfur-bearing phases and siderite and the biogeochemical cycling mechanisms likely operating in the redox stratified Lake Medard and its SWI. A prokaryote community that is to some extent compartmentalized, mediates in the interlinked $\mathrm{C}, \mathrm{N}, \mathrm{S}$, and Fe and Mn species transformations observed across the redoxcline. This community exerts an influence on the concentration gradients of other dissolved bioactive species, such as phosphate. Towards the hypolimnion, particulate matter formation involves a microaerophilic iron oxidizers/ nitrate reducer community (e.g., Gallionellacea). They promote a continuous amorphous iron aggregate export down to the ferruginous bottom water-sediment interface, where these aggregates may stabilize and/or be reductively dissolved by iron reducers (e.g., Geobacter spp.). In the sediment, stocks of pre-existing siderite and recently stabilized oxyhydroxide phases fuels anaerobic oxidation and disproportionation of by-product sulfide from MSR. In consequence, our coupled stable oxygen and sulfur isotope-based SRR estimate indicates no net sulfate reduction, despite an increased genetic potential for this pathway being deducted from 16S rRNA gene analysis and concomitant evidence for dissolved $\mathrm{SO}_{4}{ }^{2-}$ consumption, likely involving metastable FeS formation. The $\delta^{34} \mathrm{~S}_{\mathrm{CRS}}$ values in the upper part of the sediment pile are consistent with incipient and incomplete MSR-induced fractionation, yet MSR is not accompanied by dissolved sulfate depletion, probably because of a low organic substrate availability and due to bioenergetic considerations given by the presence of dissimilatory iron reducers and an abundance of Fe(III) substrates. Importantly, the $\delta^{34} \mathrm{~S}$ of the CRS pool at the lower sediment pile likely incorporates a heavier $\mathrm{S}$ signature from intermediate sulfur. Acidity generated by anaerobic S oxidation reactions proceeding near and at the SWI is neutralized by partial carbonate dissolution, which in turn provides $\mathrm{Ca}^{2+}$ ions for interstitial microcrystalline gypsum precipitation. This gypsum $\delta^{34} \mathrm{~S}$ values might fingerprint intermediate sulfur disproportionation. The carbonate mineral, on the other hand, may be undergoing recrystallization and growth below $4 \mathrm{~cm}$ sediment-depth, such as evidenced by increase $\mathrm{FeC}$ contents and the absence of corroded crystal surfaces in the lower part of the sedimentary section examined here. 
https://doi.org/10.5194/bg-2021-253

Preprint. Discussion started: 15 November 2021

(c) Author(s) 2021. CC BY 4.0 License.

(c) (i)

Appendix A.

675 Geological background

The northwest Bohemia (Czechia) was an intracontinental lowland comprised of peatlands and isolated ephemeral lakes and peat bogs in the Late Eocene. This landscape developed and expanded in association with subsidence in the Eger rift, which was in turn related to the Alpine and Pyrenean orogeny (Dèzes et al., 2004). By the Oligocene, the lowlands extended over an area $>1,000 \mathrm{~km}^{2}$ along the Sokolov and Most basins (Matys Grygar et al., 2014). Thus, organic-rich peatlands now

680 encompass humite lignite seams that correlate across the Czech-Germany boundary and toward Polish Silesia. The extended wetlands along the Eger continental rift turned, by the beginning of the Miocene - as subsidence in the rift graben increased, into a large lake affected by exhalative hydrothermal inputs (Pačes and Šmejkal, 2004) and episodically by alkaline volcanism (Ulrych et al., 2011). Deposits on this paleolake represent the last interval of the syn-rift sedimentation and consist of on 70-120 m thick carbonate-rich, kaolinitic coal-bearing claystone with several horizons of tuff material. These

685 deposits are lithostratigraphically referred to as the Cypris Formation (Kř́bek et al., 1998, 2017), and now outcrop in elevated areas of the Sokolov mining district, where they overlie the coal seams that were exploited to exhaustion in the former Medard open-cast mine.

The Miocene Cypris Formation and quaternary alluvions comprised of material largely derived from this unit functioned as the main source of sediments to the modern post-mining lacustrine system. The mineral assemblage of the stratigraphic unit

690 includes kaolinite, K-feldspar, quartz, rutile and anatase, and gypsum. It contains also analcime $\left(\mathrm{NaAlSi}_{2} \mathrm{O}_{6}\right)$, weathered pyrite, variable proportions of carbonates (calcite, Fe-dolomite, and siderite), and greigite $\left(\mathrm{Fe}_{3} \mathrm{~S}_{4}\right)$ (Murad \& Rojík, 2003, 2005). The unit is affected by localized thenardite $\left(\mathrm{Na}_{2} \mathrm{SO}_{4}\right)$ efflorescences that are associated with fluid flow along faults and fractures in subjacent rocks (Šmejkal, 1978; Pačes \& Šmejkal, 2004).

Organic matter in the Cypris claystone exhibits significant variability. These changes recorded discontinuous development of

695 widespread anoxia across the intracontinental depositional system and were accompanied also by shifts in salinity and alkalinity. This promoted lacustrine carbonate deposition (Kříbek et al., 2017). Overall, the authigenic mineral assemblage, elemental concentration trends, and the heavy $\mathrm{O}$ and $\mathrm{S}$ isotopic signatures of secondary sulfate minerals of the Cypris claystone (Fig. SM2) indicate that its deposition occurred in a large saline playa paleolake in which the oxidative weathering of sulfides, volcanic exhalations, and meteoric water-rock interactions imparted a major geochemical imprint that is 700 superimposed to that of the episodic changes in the paleolake’s redox conditions (Šmejkal, 1978; Pačes \& Šmejkal, 2004). A compilation of the $\delta^{34} \mathrm{~S}$ of the sulfate sourced from the Miocene Cypris claystone is shown in Figure B2 (Appendix B). As discussed in the main text, the dissolved sulfate of the modern redox stratified bottom waters appears to fingerprint these sources. 
https://doi.org/10.5194/bg-2021-253

Preprint. Discussion started: 15 November 2021

(c) Author(s) 2021. CC BY 4.0 License.

(c) (i)

\section{Appendix B}
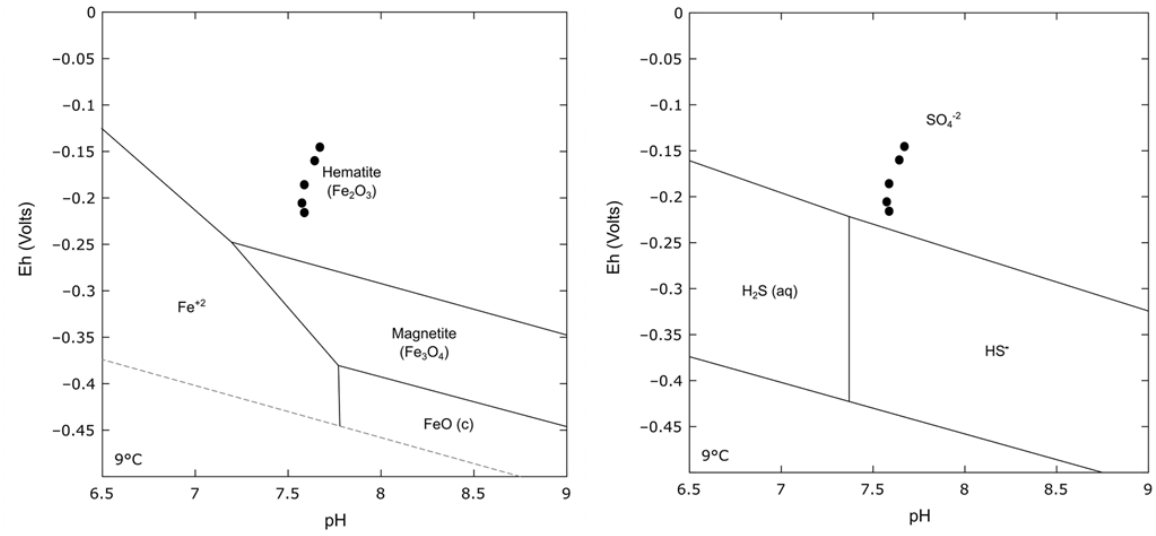

Figure B1. Pourbaix ( $\mathrm{pH}-\mathrm{Eh})$ diagram of the thermodynamically stable Fe and $\mathrm{S}$ phases in the ferruginous and sulfate-rich bottom waters of Lake Medard.

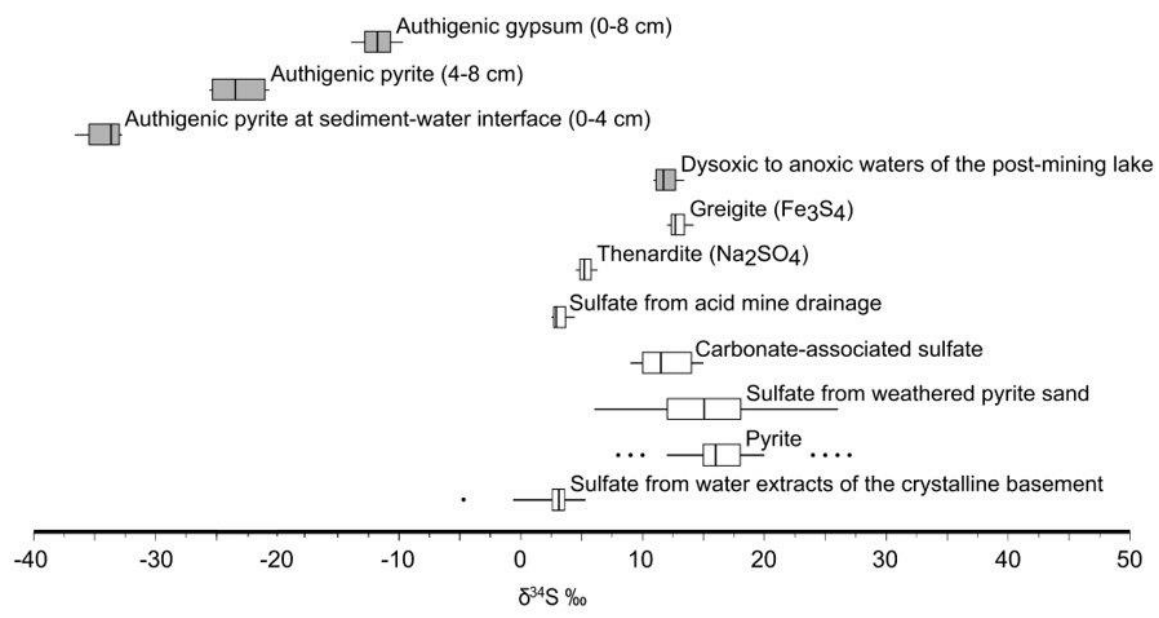

Figure B2. A comparison of the range of reported $\delta^{34} \mathrm{~S}$ values of potential sources of oxidized sulfur to Lake Medard (after Šmejkal 1978; Krs et al., 1990 for greigite), the sulfate-rich bottom water column and authigenic gypsum and pyrite in the upper anoxic sediments (i.e., this work) are also shown (filled boxes). 
https://doi.org/10.5194/bg-2021-253

Preprint. Discussion started: 15 November 2021

(c) Author(s) 2021. CC BY 4.0 License.

(c) (i)

715 Author contribution: DAP: Funding acquisition, conceptualization, methodology, data curation, formal analyses, investigation, resources, writing - original draft preparation. IMS: methodology, data curation, formal analyses. AV: methodology, data curation, formal analyses TBM: resources, formal analysis, validation, writing-original draft preparation. TP: validation, writing - original draft preparation CT: resources, validation, formal analysis, validation. writing —original draft preparation.

720 Competing interests: The authors declare that they have no conflict of interest.

\section{Acknowledgements}

This study was funded by the Czech Science Foundation (Junior Grant 19-15096Y to DAP). We sincerely thank Jiří Jan and Jakub Borovec (BC-CAS) for their technical support while sampling the bottom waters and anoxic sediments of Lake Medard. We are thankful to Karelys Umbria for wet lab assistance. We are also grateful to Stefan Lalonde (European Institute for Marine Studies, Brest) for spectroscopic concentration analyses of the water samples and to Vladislav Chrastný (Czech University of Life Sciences, Prague) for spectroscopic concentration analyses of iron and manganese in the sediment reactive fractions.

\section{References}

Antler, G., Turchyn, A. V., Rennie, V., Herut, B., and Sivan, O.: Coupled sulfur and oxygen isotope insight into bacterial sulfate reduction in the natural environment, Geochim. Cosmochim. Acta, 118, 98-117, https://doi.org/10.1016/j.gca.2013.05.005, 2013.

Bachan, A. and Kump, L. R.: The rise of oxygen and siderite oxidation during the Lomagundi event, Proc. Natl. Acad. Sci. U. S. A., 112, 6562-6567, https://doi.org/10.1073/pnas.1422319112, 2015.

Balci, N., Shanks, W. C., Mayer, B., and Mandernack, K. W.: Oxygen and sulfur isotope systematics of sulfate produced by

735 bacterial and abiotic oxidation of pyrite, Geochim. Cosmochim. Acta, 71, 3796-3811, https://doi.org/10.1016/j.gca.2007.04.017, 2007.

Barnard, A. S. and Russo, S. P.: Modelling nanoscale $\mathrm{FeS}_{2}$ formation in sulfur rich conditions, J. Mater. Chem., 19, 33893394, https://doi.org/10.1039/b819214f, 2009.

Berben, T., Sorokin, D. Y., Ivanova, N., Pati, A., Kyrpides, N., Goodwin, L. A., Woyke, T., and Muyzer, G.: Complete

740 genome sequence of Thioalkalivibrio paradoxus type strain ARh 1T, an obligately chemolithoautotrophic haloalkaliphilic sulfur-oxidizing bacterium isolated from a Kenyan soda lake, Stand. Genomic Sci., 10, https://doi.org/10.1186/s40793-0150097-7, 2015.

Bertran, E., Waldeck, A., Wing, B. A., Halevy, I., Leavitt, W. D., Bradley, A. S., and Johnston, D. T.: Oxygen isotope effects during microbial sulfate reduction: applications to sediment cell abundances, ISME J., 1-12,

745 https://doi.org/10.1038/s41396-020-0618-2, 2020. 
https://doi.org/10.5194/bg-2021-253

Preprint. Discussion started: 15 November 2021

(c) Author(s) 2021. CC BY 4.0 License.

\section{(c) (i)}

Blättler, C. L., Claire, M. W., Prave, A. R., Kirsimäe, K., Higgins, J. A., Medvedev, P. V., Romashkin, A. E., Rychanchik, D. V., Zerkle, A. L., Paiste, K., Kreitsmann, T., Millar, I. L., Hayles, J. A., Bao, H., Turchyn, A. V., Warke, M. R., and Lepland, A.: Two-billion-year-old evaporites capture Earth's great oxidation, Science 360, 320-323, https://doi.org/10.1126/science.aar2687, 2018.

Blättler, C. L., Bergmann, K. D., Kah, L. C., Gómez-Pérez, I., and Higgins, J. A.: Constraints on Meso- to Neoproterozoic seawater from ancient evaporite deposits, Earth Planet. Sci. Lett., 532, 115951, https://doi.org/10.1016/J.EPSL.2019.115951, 2020.

Boehrer, B. and Schultze, M.: Stratification of lakes, Rev. Geophys., 46, 2005, https://doi.org/10.1029/2006RG000210, 2008.

755 Boehrer, B., Dietz, S., Rohden, C. von, Kiwel, U., Jöhnk, K. D., Naujoks, S., Ilmberger, J., and Lessmann, D.: Doublediffusive deep water circulation in an iron-meromictic lake, Geochemistry, Geophys. Geosystems, 10, 6006, https://doi.org/10.1029/2009GC002389, 2009.

Böttcher, M. E., Thamdrup, B., and Vennemann, T. W.: Anaerobic sulfide oxidation and stable isotope fractionation associated with bacterial sulfur disproportionation in the presence of $\mathrm{MnO}_{2}$, Geochim. Cosmochim. Acta, 65, 1573-1581, https://doi.org/10.1016/S0016-7037(00)00622-0, 2001.

Böttcher, M. E., Hespenheide, B., Brumsack, H. J., and Bosselmann, K.: Stable isotope biogeochemistry of the sulfur cycle in modern marine sediments: I. Seasonal dynamics in a temperate intertidal sandy surface sediment, Isotopes Environ. Health Stud., 40, 267-283, https://doi.org/10.1080/10256010410001678071, 2004.

Böttcher, M. E., Thamdrup, B., Gehre, M., and Theune, A.: ${ }^{34} \mathrm{~S} /{ }^{32} \mathrm{~S}$ and ${ }^{18} \mathrm{O} /{ }^{16} \mathrm{O}$ fractionation during sulfur disproportionation by Desulfobulbus propionicus, Geomicrobiol. J., 22, 219-226, https://doi.org/10.1080/01490450590947751, 2005 b.

Bottrell, S. H. and Newton, R. J.: Reconstruction of changes in global sulfur cycling from marine sulfate isotopes, EarthScience Rev., 75, 59-83, https://doi.org/10.1016/j.earscirev.2005.10.004, 2006.

Bouška, V., Pešek, J., and Žák, K.: Values of $\delta^{34} \mathrm{~S}$ in iron disulphides of the North Bohemian Lignite Basin, Czech Republic, Geol. Soc. London, Spec. Publ., 125, 261-267, https://doi.org/10.1144/GSL.SP.1997.125.01.22, 1997.

770 Brüchert, V.: Physiological and ecological aspects of sulfur isotope fractionation during bacterial sulfate reduction, Spec. Pap. Geol. Soc. Am., 379, 1-16, https://doi.org/10.1130/0-8137-2379-5.1, 2004.

Brunet, R. C. and Garcia-Gil, L. J.: Sulfide-induced dissimilatory nitrate reduction to ammonia in anaerobic freshwater sediments, FEMS Microbiol. Ecol., 21, 131-138, https://doi.org/10.1111/J.1574-6941.1996.TB00340.X, 1996.

Brunner, B., Bernasconi, S. M., Kleikemper, J., and Schroth, M. H.: A model for oxygen and sulfur isotope fractionation in 775 sulfate during bacterial sulfate reduction processes, Geochim. Cosmochim. Acta, 69, 4773-4785, https://doi.org/10.1016/j.gca.2005.04.017, 2005.

Butler, J. E., Young, N. D., and Lovley, D. R.: Evolution from a respiratory ancestor to fill syntrophic and fermentative niches: comparative genomics of six Geobacteraceae species, BMC Genomics 2009 101, 10, 1-10, https://doi.org/10.1186/1471-2164-10-103, 2009. 
https://doi.org/10.5194/bg-2021-253

Preprint. Discussion started: 15 November 2021

(c) Author(s) 2021. CC BY 4.0 License.

(c) (i)

780 Canfield, D. E.: Reactive iron in marine sediments, Geochim. Cosmochim. Acta, 53, 619-632, https://doi.org/10.1016/00167037(89)90005-7, 1989.

Canfield, D. E.: Biogeochemistry of Sulfur Isotopes, Rev. Mineral. Geochemistry, 43, 607-636, https://doi.org/10.2138/GSRMG.43.1.607, 2001.

Canfield, D. E. and Berner, R. A.: Dissolution and pyritization of magnetite in anoxie marine sediments, Geochim.

785 Cosmochim. Acta, 51, 645-659, https://doi.org/10.1016/0016-7037(87)90076-7, 1987.

Canfield, D. E., Raiswell, R., Westrich, J. T., Reaves, C. M., and Berner, R. A.: The use of chromium reduction in the analysis of reduced inorganic sulfur in sediments and shales, Chem. Geol., 54, 149-155, https://doi.org/10.1016/00092541(86)90078-1, 1986.

Canfield, D. E., Thamdrup, B., and Hansen, J. W.: The anaerobic degradation of organic matter in Danish coastal sediments:

790 Iron reduction, manganese reduction, and sulfate reduction, Geochim. Cosmochim. Acta, 57, 3867-3883,

https://doi.org/10.1016/0016-7037(93)90340-3, 1993.

Davison, W.: Iron and manganese in lakes, Earth Sci. Rev., 34, 119-163, https://doi.org/10.1016/0012-8252(93)90029-7, 1993.

Denimal, S., Bertrand, C., Mudry, J., Paquette, Y., Hochart, M., and Steinmann, M.: Evolution of the aqueous geochemistry

795 of mine pit lakes - Blanzy-Montceau-les-Mines coal basin (Massif Central, France): Origin of sulfate contents; effects of stratification on water quality, Appl. Geochemistry, 20, 825-839, https://doi.org/10.1016/j.apgeochem.2004.11.015, 2005.

DeWeerd, K. A., Mandelco, L., Tanner, R. S., Woese, C. R., and Suflita, J. M.: Desulfomonile tiedjei gen. nov. and sp. nov., a novel anaerobic, dehalogenating, sulfate-reducing bacterium, Arch. Microbiol. 1990 1541, 154, 23-30, https://doi.org/10.1007/BF00249173, 1990.

800 Dèzes P, Schmid SM, Ziegler PA (2004) Evolution of the European Cenozoic Rift System: interaction of the Alpine and Pyrenean orogens with their foreland lithosphere. Tectonophysics 389, 1-33.

Dupalová, T., Sracek, O., Vencelides, Z., and , K. Žák: The origin of thermal waters in the northeastern part of the Eger Rift, Czech Republic, Appl. Geochemistry, 27, 689-702, https://doi.org/10.1016/j.apgeochem.2011.11.016, 2012.

Emerson, D. and Moyer, C.: Isolation and characterization of novel iron-oxidizing bacteria that grow at circumneutral pH,

805 Appl. Environ. Microbiol., 63, 4784-4792, https://doi.org/10.1128/aem.63.12.4784-4792.1997, 1997.

Fakhraee, M., Hancisse, O., Canfield, D. E., Crowe, S. A., and Katsev, S.: Proterozoic seawater sulfate scarcity and the evolution of ocean-atmosphere chemistry, Nat. Geosci. 2019 125, 12, 375-380, https://doi.org/10.1038/s41561-019-0351-5, 2019.

Flores, G. E., Hunter, R. C., Liu, Y., Mets, A., Schouten, S., and Reysenbach, A. L.: Hippea jasoniae sp. nov. and Hippea

810 alviniae sp. nov., thermoacidophilic members of the class Deltaproteobacteria isolated from deep-sea hydrothermal vent deposits, Int. J. Syst. Evol. Microbiol., 62, 1252-1258, https://doi.org/10.1099/ijs.0.033001-0, 2012. 
https://doi.org/10.5194/bg-2021-253

Preprint. Discussion started: 15 November 2021

(c) Author(s) 2021. CC BY 4.0 License.

\section{(c) (1)}

Fritz, P., Basharmal, G. M., Drimmie, R. J., Ibsen, J., and Qureshi, R. M.: Oxygen isotope exchange between sulphate and water during bacterial reduction of sulphate, Chem. Geol. Isot. Geosci. Sect., 79, 99-105, https://doi.org/10.1016/01689622(89)90012-2, 1989.

815 Gallagher, K. L., Dupraz, C., and Visscher, P. T.: Two opposing effects of sulfate reduction on carbonate precipitation in normal marine, hypersaline, and alkaline environments: COMMENT, Geology, 42, e313-e314, https://doi.org/10.1130/G34639C.1, 2014.

Geszvain, K., Yamaguchi, A., Maybee, J., and Tebo, B. M.: Mn(II) oxidation in Pseudomonas putida GB-1 is influenced by flagella synthesis and surface substrate, Arch. Microbiol., 193, 605-614, https://doi.org/10.1007/s00203-011-0702-0, 2011.

Goldberg, T., Archer, C., Vance, D., Thamdrup, B., McAnena, A., and Poulton, S. W.: Controls on Mo isotope fractionations in a Mn-rich anoxic marine sediment, Gullmar Fjord, Sweden, Chem. Geol., 296-297, 73-82, https://doi.org/10.1016/J.CHEMGEO.2011.12.020, 2012.

Gwak, J.-H., Jung, M.-Y., Hong, H., Kim, J.-G., Quan, Z.-X., Reinfelder, J. R., Spasov, E., Neufeld, J. D., Wagner, M., and Rhee, S.-K.: Archaeal nitrification is constrained by copper complexation with organic matter in municipal wastewater treatment plants, ISME J. 2019 142, 14, 335-346, https://doi.org/10.1038/s41396-019-0538-1, 2019.

Hambright, K. D., Gophen, M., and Serruya, S.: Influence of long-term climatic changes on the stratification of a subtropical, warm monomictic lake, Limnol. Oceanogr., 39, 1233-1242, https://doi.org/10.4319/LO.1994.39.5.1233, 1994. Holmes, D. E., O’Neil, R. A., Vrionis, H. A., N'Guessan, L. A., Ortiz-Bernad, I., Larrahondo, M. J., Adams, L. A., Wards, J. A., Nicoll, J. S., Nevin, K. P., Chavan, M. A., Johnson, J. P., Long, P. E., and Lovley, D. R.: Subsurface clade of

Geobacteraceae that predominates in a diversity of Fe(III)-reducing subsurface environments, ISME J., 1, 663-677, https://doi.org/10.1038/ismej.2007.85, 2007.

Holmkvist, L., Ferdelman, T. G., and Jørgensen, B. B.: A cryptic sulfur cycle driven by iron in the methane zone of marine sediment (Aarhus Bay, Denmark), Geochim. Cosmochim. Acta, 75, 3581-3599, https://doi.org/10.1016/J.GCA.2011.03.033, 2011.

835 Jewell, T. N. M., Karaoz, U., Brodie, E. L., Williams, K. H., and Beller, H. R.: Metatranscriptomic evidence of pervasive and diverse chemolithoautotrophy relevant to C, S, N and Fe cycling in a shallow alluvial aquifer, ISME J., 10, 2106-2117, https://doi.org/10.1038/ismej.2016.25, 2016.

Jewell, T. N. M., Karaoz, U., Bill, M., Chakraborty, R., Brodie, E. L., Williams, K. H., and Beller, H. R.: Metatranscriptomic analysis reveals unexpectedly diverse microbial metabolism in a biogeochemical hot spot in an alluvial aquifer, Front.

840 Microbiol., 8, https://doi.org/10.3389/fmicb.2017.00040, 2017.

Jiang, C. Z. and Tosca, N. J.: Fe(II)-carbonate precipitation kinetics and the chemistry of anoxic ferruginous seawater, Earth Planet. Sci. Lett., 506, 231-242, https://doi.org/10.1016/J.EPSL.2018.11.010, 2019.

Johnston, D. T., Gill, B. C., Masterson, A., Beirne, E., Casciotti, K. L., Knapp, A. N., and Berelson, W.: Placing an upper limit on cryptic marine sulphur cycling, Nature, 513, 530-533, https://doi.org/10.1038/nature13698, 2014. 
https://doi.org/10.5194/bg-2021-253

Preprint. Discussion started: 15 November 2021

(c) Author(s) 2021. CC BY 4.0 License.

\section{(c) (1)}

845 Jung, M.-Y., Islam, M. A., Gwak, J.-H., Kim, J.-G., and Rhee, S.-K.: Nitrosarchaeum koreense gen. nov., sp. nov., an aerobic and mesophilic, ammonia-oxidizing archaeon member of the phylum Thaumarchaeota isolated from agricultural soil, Int. J. Syst. Evol. Microbiol., 68, 3084-3095, https://doi.org/10.1099/IJSEM.0.002926, 2018.

Keeling, C. D.: The concentration and isotopic abundances of carbon dioxide in rural and marine air, Geochim. Cosmochim. Acta, 24, 277-298, https://doi.org/10.1016/0016-7037(61)90023-0, 1961.

850 Koeksoy, E., Halama, M., Konhauser, K. O., and Kappler, A.: Using modern ferruginous habitats to interpret Precambrian banded iron formation deposition, Int. J. Astrobiol., 15, 205-217, https://doi.org/10.1017/S1473550415000373, 2016.

Kojima, H. and Fukui, M.: Sulfuritalea hydrogenivorans gen. nov., sp. nov., a facultative autotroph isolated from a freshwater lake, Int. J. Syst. Evol. Microbiol., 61, 1651-1655, https://doi.org/10.1099/ijs.0.024968-0, 2011.

Kojima, H., Watanabe, T., Iwata, T., and Fukui, M.: Identification of Major Planktonic Sulfur Oxidizers in Stratified

855 Freshwater Lake, PLoS One, 9, e93877, https://doi.org/10.1371/journal.pone.0093877, 2014.

Konhauser, K. O., Amskold, L., Lalonde, S. V., Posth, N. R., Kappler, A., and Anbar, A.: Decoupling photochemical Fe(II) oxidation from shallow-water BIF deposition, Earth Planet. Sci. Lett., 258, 87-100,

https://doi.org/10.1016/J.EPSL.2007.03.026, 2007.

Kostka, J. E., Luther, G. W., and Nealson, K. H.: Chemical and biological reduction of Mn (III)-pyrophosphate complexes:

860 Potential importance of dissolved Mn (III) as an environmental oxidant, Geochim. Cosmochim. Acta, 59, 885-894, https://doi.org/10.1016/0016-7037(95)00007-0, 1995.

Kříbek B, Strnad M, Bohâcek Z, Sýkorová I, Čejka J, Sobalík Z.: Geochemistry of Miocene lacustrine sediments from the Sokolov Coal Basin (Czech Republic), Intl. J. Coal Geol. 37, 207-233, 1998.

865 Kříbek, B., Knésl, I., Rojík, P., Sýkorová, I., and Martínek, K.: Geochemical history of a Lower Miocene Lake, the Cypris Formation, Sokolov Basin, Czech Republic, J. Paleolimnol., 58, 169-190, https://doi.org/10.1007/s10933-017-9970-2, 2017.

Lambrecht, N., Wittkop, C., Katsev, S., Fakhraee, M., and Swanner, E. D.: Geochemical Characterization of Two

Ferruginous Meromictic Lakes in the Upper Midwest, USA, J. Geophys. Res. Biogeosciences, 123, 3403-3422, https://doi.org/10.1029/2018JG004587, 2018.

870 Krs M, Krsová M, Pruner P, Zeman A, Novák F, Jansa J (1990) A petromagnetic study of Miocene rocks bearing microorganic material and the magnetic mineral greigite (Sokolov and Cheb basins, Czechoslovakia). Physics of the Earth and Planetary Interiors 63, 98-112.

Lehtovirta-Morley, L. E.: Ammonia oxidation: Ecology, physiology, biochemistry and why they must all come together, https://doi.org/10.1093/femsle/fny058, 1 May 2018.

875 Li, C., Planavsky, N. J., Love, G. D., Reinhard, C. T., Hardisty, D., Feng, L., Bates, S. M., Huang, J., Zhang, Q., Chu, X., and Lyons, T. W.: Marine redox conditions in the middle Proterozoic ocean and isotopic constraints on authigenic carbonate formation: Insights from the Chuanlinggou Formation, Yanshan Basin, North China, Geochim. Cosmochim. Acta, 150, 90105, https://doi.org/10.1016/J.GCA.2014.12.005, 2015. 
https://doi.org/10.5194/bg-2021-253

Preprint. Discussion started: 15 November 2021

(c) Author(s) 2021. CC BY 4.0 License.

\section{(c) (1)}

Lin, W., Deng, A., Wang, Z., Li, Y., Wen, T., Wu, L.-F., Wu, M., and Pan, Y.: Genomic insights into the uncultured genus

'Candidatus Magnetobacterium' in the phylum Nitrospirae, ISME J. 2014 812, 8, 2463-2477,

https://doi.org/10.1038/ismej.2014.94, 2014.

Lovley, D.: Dissimilatory Fe(III)- and Mn(IV)-Reducing prokaryotes, in: The Prokaryotes: Prokaryotic Physiology and Biochemistry, Springer, Berlin, Heidelberg, 287-308, https://doi.org/10.1007/978-3-642-30141-4_69, 2013.

Lovley, D. R. and Phillips, E. J. P.: Manganese inhibition of microbial iron reduction in anaerobic sediments, Geomicrobiol.

J., 6, 145-155, https://doi.org/10.1080/01490458809377834, 1988.

Lovley, D. R. and Phillips, E. J. P.: Novel processes for anaerobic sulfate production from elemental sulfur by sulfatereducing bacteria, Appl. Environ. Microbiol., 60, 2394-2399, https://doi.org/10.1128/aem.60.7.2394-2399.1994, 1994.

Massaro, F. R., Rubbo, M., and Aquilano, D.: Theoretical Equilibrium Morphology of Gypsum (CaSO4·2H2O). 1. A Syncretic Strategy to Calculate the Morphology of Crystals, Cryst. Growth Des., 10, 2870-2878,

890 https://doi.org/10.1021/CG900660V, 2010.

Matys Grygar T, Mach K, Schnabl P, Pruner P, Laurin J, Martinez M.:A lacustrine record of the early stage of the Miocene Climatic Optimum in Central Europe from the Most Basin, Ohře (Eger) Graben, Czech Republic, Geological Magazine 151, 1013-1033, 2014.

Michiels, C. C., Darchambeau, F., Roland, F. A. E., Morana, C., Llirós, M., García-Armisen, T., Thamdrup, B., Borges, A.

895 V., Canfield, D. E., Servais, P., Descy, J. P., and Crowe, S. A.: Iron-dependent nitrogen cycling in a ferruginous lake and the nutrient status of Proterozoic oceans, Nat. Geosci., 10, 217-221, https://doi.org/10.1038/ngeo2886, 2017.

Murad, E. and Rojík, P.: Iron mineralogy of mine-drainage precipitates as environmental indicators: review of current concepts and a case study from the Sokolov Basin, Czech Republic, Clay Miner., 40, 427-440, https://doi.org/10.1180/0009855054040181, 2005.

900 Murad E, Rojík P Iron-rich precipitates in a mine drainage environment: Influence of pH on mineralogy. American Mineralogist 88, 1915-1918. 2003.

Mußmann, M., Brito, I., Pitcher, A., Damsté, J. S. S., Hatzenpichler, R., Richter, A., Nielsen, J. L., Nielsen, P. H., Müller, A., Daims, H., Wagner, M., and Head, I. M.: Thaumarchaeotes abundant in refinery nitrifying sludges express amoA but are not obligate autotrophic ammonia oxidizers, Proc. Natl. Acad. Sci. U. S. A., 108, 16771,

905 https://doi.org/10.1073/PNAS.1106427108, 2011.

Namgung, S., Guo, B., Sasaki, K., Lee, S. S., and Lee, G.: Macroscopic and microscopic behaviors of Mn(II) (ad)sorption to goethite with the effects of dissolved carbonates under anoxic conditions, Geochim. Cosmochim. Acta, 277, 300-319, https://doi.org/10.1016/j.gca.2020.03.036, 2020.

Noseck, U., Brasser, T., Rajlich, P., Laciok, A., and Hercik, M.: Mobility of uranium in tertiary argillaceous sediments - A 910 natural analogue study, in: Radiochimica Acta, 797-803, https://doi.org/10.1524/ract.92.9.797.54972, 2004. 
https://doi.org/10.5194/bg-2021-253

Preprint. Discussion started: 15 November 2021

(c) Author(s) 2021. CC BY 4.0 License.

\section{(c) (1)}

Oude Elferink, S. J. W. H., Akkermans-van Met, W, M., Bogte, J. J., and Stams, A. J. M.: Desulfobacca acetoxidans gen. nov., sp. nov., a novel acetate-degrading sulfate reducer isolated from sulfidogenic granular sludge, Int. J. Syst. Bacteriol., 49, 345-350, https://doi.org/10.1099/00207713-49-2-345, 1999.

Pačes, T. and Šmejkal, V.: Magmatic and fossil components of thermal and mineral waters in the Eger River continental rift (Bohemian massif, central Europe), in: Water-Rock Interaction. Proc. 11th International Symposium, edited by: Wanty, R. B. and Seal II, R. R., Taylor and Francis Group, London, 167-172, 2004.

Pellerin, A., Antler, G., Holm, S. A., Findlay, A. J., Crockford, P. W., Turchyn, A. V., Jørgensen, B. B., and Finster, K.: Large sulfur isotope fractionation by bacterial sulfide oxidation, Sci. Adv., 5, eaaw1480, https://doi.org/10.1126/SCIADV.AAW1480, 2019.

Pérez-Rodríguez, I., Rawls, M., Coykendall, D. K., and Foustoukos, D. I.: Deferrisoma palaeochoriense sp. nov., a thermophilic, iron(III)-reducing bacterium from a shallow-water hydrothermal vent in the Mediterranean Sea, Int. J. Syst. Evol. Microbiol., 66, 830-836, https://doi.org/10.1099/IJSEM.0.000798, 2016.

Petrash, D. A., Gingras, M. K., Lalonde, S. V., Orange, F., Pecoits, E., and Konhauser, K. O.: Dynamic controls on accretion and lithification of modern gypsum-dominated thrombolites, Los Roques, Venezuela, Sediment. Geol., 245-246, 29-47, https://doi.org/10.1016/j.sedgeo.2011.12.006, 2012.

Petrash, D. A., Gueneli, N., Brocks, J. J., Méndez-Dot, J. A., González-Arismendi, G., Poulton, S. W., and Konhauser, K. O.: Black shale deposition and early diagenetic dolomite cementation during Oceanic Anoxic Event 1: The mid-Cretaceous Maracaibo Platform, Northwestern South America, Am. J. Sci., 316, 669-711, https://doi.org/10.2475/07.2016.03, 2016. Petrash, D. A., Jan, J., Sirová, D., Osafo, N. O.-A., and Borovec, J.: Iron and nitrogen cycling, bacterioplankton community composition and mineral transformations involving phosphorus stabilisation in the ferruginous hypolimnion of a post-mining lake., Environ. Sci. Process. Impacts, 20, 1414-1426, https://doi.org/10.1039/c8em00328a, 2018.

Petrash, D. A., Bialik, O. M., Staudigel, P. T., Konhauser, K. O., and Budd, D. A.: Biogeochemical reappraisal of the freshwater-seawater mixing-zone diagenetic model, Sedimentology, 68, 1797-1830, https://doi.org/10.1111/sed.12849, 2021.

935 Philippot, P., Van Kranendonk, M., Van Zuilen, M., Lepot, K., Rividi, N., Teitler, Y., Thomazo, C., Blanc-Valleron, M. M., Rouchy, J. M., Grosch, E., and de Wit, M.: Early traces of life investigations in drilling Archean hydrothermal and sedimentary rocks of the Pilbara Craton, Western Australia and Barberton Greenstone Belt, South Africa, 8, 649-663, https://doi.org/10.1016/J.CRPV.2009.06.006, 2009.

Phillips, D. L. and Gregg, J. W.: Uncertainty in source partitioning using stable isotopes, Oecologia, 127, 171-179,

940 https://doi.org/10.1007/s004420000578, 2001.

Poulton, S. W. and Canfield, D. E.: Development of a sequential extraction procedure for iron: Implications for iron partitioning in continentally derived particulates, Chem. Geol., 214, 209-221, https://doi.org/10.1016/j.chemgeo.2004.09.003, 2005. 
https://doi.org/10.5194/bg-2021-253

Preprint. Discussion started: 15 November 2021

(c) Author(s) 2021. CC BY 4.0 License.

(c) (i)

Poulton, S. W. and Canfield, D. E.: Ferruginous Conditions: A Dominant Feature of the Ocean through Earth's History, 7,

107-112, https://doi.org/10.2113/GSELEMENTS.7.2.107, 2011.

Poulton, S. W., Krom, M. D., and Raiswell, R.: A revised scheme for the reactivity of iron (oxyhydr)oxide minerals towards dissolved sulfide, Geochim. Cosmochim. Acta, 68, 3703-3715, https://doi.org/10.1016/j.gca.2004.03.012, 2004.

Rapantová, N., Krzeszowski, Ś., Grmela, A., and Wolkersdorfer, C.: Quantitative Assessment of Mine Water Sources Based on the General Mixing Equation and Multivariate Statistics, Mine Water Environ., 31, 252-265,

950 https://doi.org/10.1007/s10230-012-0192-6, 2012.

Rasmussen, B., Krapež, B., Muhling, J. R., and Suvorova, A.: Precipitation of iron silicate nanoparticles in early Precambrian oceans marks Earth's first iron age, Geology, 43, 303-306, https://doi.org/10.1130/G36309.1, 2015.

Rennie, V. C. F. and Turchyn, A. V.: The preservation of $\delta \mathrm{SSO} 434$ and $\delta \mathrm{OSO} 418$ in carbonate-associated sulfate during marine diagenesis: A 25 Myr test case using marine sediments, Earth Planet. Sci. Lett., 395, 13-23,

955 https://doi.org/10.1016/j.epsl.2014.03.025, 2014.

Rickard, D. and Morse, J. W.: Acid volatile sulfide (AVS), https://doi.org/10.1016/j.marchem.2005.08.004, 20 December 2005.

Robertson, E. K. and Thamdrup, B.: The fate of nitrogen is linked to iron(II) availability in a freshwater lake sediment, Geochim. Cosmochim. Acta, 205, 84-99, https://doi.org/10.1016/j.gca.2017.02.014, 2017.

960 Rodríguez-Ruiz, I., Van Driessche, A. E. S., Veesler, S., García-Ruiz, J. M., and IUCr: Nucleation of gypsum at low supersaturations, 67, 461-462, https://doi.org/10.1107/S0108767311088386, 2011.

Scholz, F.: Identifying oxygen minimum zone-type biogeochemical cycling in Earth history using inorganic geochemical proxies, Earth-Science Rev., 184, 29-45, https://doi.org/10.1016/j.earscirev.2018.08.002, 2018.

Scholz, F. and Neumann, T.: Trace element diagenesis in pyrite-rich sediments of the Achterwasser lagoon, SW Baltic Sea,

965 Mar. Chem., 107, 516-532, https://doi.org/10.1016/j.marchem.2007.08.005, 2007.

Schoonen, M.: Mechanisms of sedimentary pyrite formation, in: Sulfur biogeochemistry—Past and present, Geological Society of America Special Paper 379, edited by: Amend, J. P., Edwards, K. J., and Lyons, T. W., Geological Society of America, Boulder, Colorado, 117-134., 2004.

Schultze, M., Pokrandt, K. H., and Hille, W.: Pit lakes of the Central German lignite mining district: Creation, morphometry 970 and water quality aspects, 40, 148-155, https://doi.org/10.1016/J.LIMNO.2009.11.006, 2010.

Simon, B., Bienfait, M., and IUCr: Structure et mécanisme de croissance du gypse, 19, 750-756, https://doi.org/10.1107/S0365110X65004310, 1965.

Slomp, C. P., Malschaert, J. F. P., Lohse, L., and Van Raaphorst, W.: Iron and manganese cycling in different sedimentary environments on the North Sea continental margin, Cont. Shelf Res., 17, 1083-1117, https://doi.org/10.1016/S0278-

975 4343(97)00005-8, 1997. 
https://doi.org/10.5194/bg-2021-253

Preprint. Discussion started: 15 November 2021

(c) Author(s) 2021. CC BY 4.0 License.

Šmejkal, V.: Oxygen isotopic composition of sulphates from some mineral waters and mine waters in western Bohemia, in: Isotope hydrology, 1978: Proceedings of IAEA; Vienna; International symposium on isotope hydrology; Neuherberg, Germany, 19 - 23 Jun 1978; IAEA-SM-228/4, 83-97, 1978.

Šmejkal, V.: Isotopic composition of carbonates and differences in deposition environment during the Miocene lacustrine sedimentation in the Krusne Hory graben, Zentralinstitut für Isot. und Strahlenforschung, Leipzig, 372-379, 1984.

Soetaert, K., Hofmann, A. F., Middelburg, J. J., Meysman, F. J. R., and Greenwood, J.: The effect of biogeochemical processes on pH, Mar. Chem., 105, 30-51, https://doi.org/10.1016/j.marchem.2006.12.012, 2007.

Starke, R., Müller, M., Gaspar, M., Marz, M., Küsel, K., Totsche, K. U., von Bergen, M., and Jehmlich, N.: Candidate Brocadiales dominates $\mathrm{C}, \mathrm{N}$ and $\mathrm{S}$ cycling in anoxic groundwater of a pristine limestone-fracture aquifer, J. Proteomics, 152, 985 153-160, https://doi.org/10.1016/j.jprot.2016.11.003, 2017.

Sun, B., Cole, J. R., and Tiedje, J. M.: Desulfomonile limimaris sp. nov., an anaerobic dehalogenating bacterium from marine sediments., Int. J. Syst. Evol. Microbiol., 51, 365-371, https://doi.org/10.1099/00207713-51-2-365, 2001.

Swanner, E. D., Lambrecht, N., Wittkop, C., Harding, C., Katsev, S., Torgeson, J., and Poulton, S. W.: The biogeochemistry of ferruginous lakes and past ferruginous oceans, Earth-Science Rev., 103430,

990 https://doi.org/10.1016/j.earscirev.2020.103430, 2020.

Taylor, B. E., Wheeler, M. C., and Nordstrom, D. K.: Isotope composition of sulphate in acid mine drainage as measure of bacterial oxidation, Nature, 308, 538-541, https://doi.org/10.1038/308538a0, 1984a.

Taylor, B. E., Wheeler, M. C., and Nordstrom, D. K.: Stable isotope geochemistry of acid mine drainage: Experimental oxidation of pyrite, Geochim. Cosmochim. Acta, 48, 2669-2678, https://doi.org/10.1016/0016-7037(84)90315-6, 1984b.

995 Tebo, B. M., Johnson, H. A., McCarthy, J. K., and Templeton, A. S.: Geomicrobiology of manganese(II) oxidation, https://doi.org/10.1016/j.tim.2005.07.009, 1 September 2005.

Thomazo, C., Brayard, A., Elmeknassi, S., Vennin, E., Olivier, N., Caravaca, G., Escarguel, G., Fara, E., Bylund, K. G., Jenks, J. F., Stephen, D. A., Killingsworth, B., Sansjofre, P., and Cartigny, P.: Multiple sulfur isotope signals associated with the late Smithian event and the Smithian/Spathian boundary, Earth-Science Rev., 195, 96-113,

1000 https://doi.org/10.1016/J.EARSCIREV.2018.06.019, 2019.

Toran, L. and Harris, R. F.: Interpretation of sulfur and oxygen isotopes in biological and abiological sulfide oxidation, Geochim. Cosmochim. Acta, 53, 2341-2348, https://doi.org/10.1016/0016-7037(89)90356-6, 1989.

Trettin, R., Gläser, H. R., Schultze, M., and Strauch, G.: Sulfur isotope studies to quantify sulfate components in water of flooded lignite open pits - Lake Goitsche, Germany, Appl. Geochemistry, 22, 69-89,

1005 https://doi.org/10.1016/j.apgeochem.2006.07.020, 2007.

Umbría-Salinas, K., Valero, A., Jan, J., Borovec, J., Chrastný, V., and Petrash, D. A.: Redox-driven geochemical partitioning of metal(loid)s in the iron-rich anoxic sediments of a recently flooded lignite mine pit: Lake Medard, NW Czechia, J.

Hazard. Mater. Adv., 100009, https://doi.org/10.1016/J.HAZADV.2021.100009, 2021. 
https://doi.org/10.5194/bg-2021-253

Preprint. Discussion started: 15 November 2021

(c) Author(s) 2021. CC BY 4.0 License.

(c) (i)

Ulrych J, Dostal J, Adamović J, Jelínek E, Špaček P, Hegner E, Balogh K. : Recurrent Cenozoic volcanic activity in the

Bohemian Massif (Czech Republic). Lithos 123, 133-144., 2011

van de Velde, S. J., Reinhard, C. T., Ridgwell, A., and Meysman, F. J. R.: Bistability in the redox chemistry of sediments and oceans, Proc. Natl. Acad. Sci. U. S. A., 117, 33043-33050, https://doi.org/10.1073/PNAS.2008235117, 2021.

van der Voort, E. and Hartman, P.: The habit of gypsum and solvent interaction, J. Cryst. Growth, 112, 445-450, https://doi.org/10.1016/0022-0248(91)90321-U, 1991.

1015 Waite, D. W., Chuvochina, M., Pelikan, C., Parks, D. H., Yilmaz, P., Wagner, M., Loy, A., Naganuma, T., Nakai, R., Whitman, W. B., Hahn, M. W., Kuever, J., and Hugenholtz, P.: Proposal to reclassify the proteobacterial classes Deltaproteobacteria and Oligoflexia, and the phylum Thermodesulfobacteria into four phyla reflecting major functional capabilities, Int. J. Syst. Evol. Microbiol., 70, 5972-6016, https://doi.org/10.1099/IJSEM.0.004213, 2020.

Wards, L. M., Bertran, E., and Johnston, D. T.: Expanded Genomic Sampling of the Desulfobulbales Reveals Distribution and Evolution of Sulfur Metabolisms, 2021.02.08.430318, https://doi.org/10.1101/2021.02.08.430318, 2021.

Weber, K. A., Achenbach, L. A., and Coates, J. D.: Microorganisms pumping iron: Anaerobic microbial iron oxidation and reduction, Nat. Rev. Microbiol., 4, 752-764, https://doi.org/10.1038/nrmicro1490, 2006.

Weelink, S. A. B., Van Doesburg, W., Saia, F. T., Rijpstra, W. I. C., Röling, W. F. M., Smidt, H., and Stams, A. J. M.: A strictly anaerobic betaproteobacterium Georgfuchsia toluolica gen. nov., sp. nov. degrades aromatic compounds with Fe(III),

$1025 \mathrm{Mn}(\mathrm{IV})$ or nitrate as an electron acceptor, FEMS Microbiol. Ecol., 70, 575-585, https://doi.org/10.1111/j.15746941.2009.00778.x, 2009.

Weinlich, F. H., Bräuer, K., Kämpf, H., Strauch, G., Tesař, J., and Weise, S. M.: An active subcontinental mantle volatile system in the western Eger rift, Central Europe: Gas flux, isotopic (He, C, and N) and compositional fingerprints, Geochim. Cosmochim. Acta, 63, 3653-3671, https://doi.org/10.1016/S0016-7037(99)00187-8, 1999.

1030 Wright, M. H., Geszvain, K., Oldham, V. E., Luther, G. W., and Tebo, B. M.: Oxidative formation and removal of complexed Mn(III) by Pseudomonas species, Front. Microbiol., 9, 560, https://doi.org/10.3389/fmicb.2018.00560, 2018. Van Der Zee, C. and Van Raaphorst, W.: Manganese oxide reactivity in North Sea sediments, J. Sea Res., 52, 73-85, https://doi.org/10.1016/j.seares.2003.10.005, 2004.

Zerkle, A. L., Jones, D. S., Farquhar, J., and Macalady, J. L.: Sulfur isotope values in the sulfidic Frasassi cave system,

1035 central Italy: A case study of a chemolithotrophic S-based ecosystem, Geochim. Cosmochim. Acta, 173, 373-386, https://doi.org/10.1016/J.GCA.2015.10.028, 2016. 